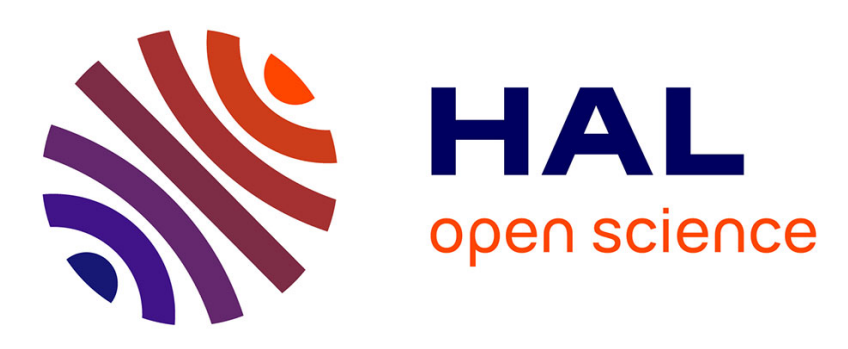

\title{
Spatial variability of Quaternary denudation rates across a volcanic ocean island (Santo Antão, Cape Verde) from cosmogenic $3 \mathrm{He}$
}

Camille Litty, Julien Charreau, Pierre-henri Blard, Raphaël Pik, Sébastien

Nomade

\section{To cite this version:}

Camille Litty, Julien Charreau, Pierre-henri Blard, Raphaël Pik, Sébastien Nomade. Spatial variability of Quaternary denudation rates across a volcanic ocean island (Santo Antão, Cape Verde) from cosmogenic 3 He. Geomorphology, 2021, 375, pp.107557. 10.1016/j.geomorph.2020.107557. hal-03089201

\section{HAL Id: hal-03089201 \\ https://cnrs.hal.science/hal-03089201}

Submitted on 28 Dec 2020

HAL is a multi-disciplinary open access archive for the deposit and dissemination of scientific research documents, whether they are published or not. The documents may come from teaching and research institutions in France or abroad, or from public or private research centers.
L'archive ouverte pluridisciplinaire HAL, est destinée au dépôt et à la diffusion de documents scientifiques de niveau recherche, publiés ou non, émanant des établissements d'enseignement et de recherche français ou étrangers, des laboratoires publics ou privés. 
1 Spatial variability of Quaternary denudation rates across a volcanic ocean

2 island (Santo Antão, Cape Verde) from cosmogenic ${ }^{3} \mathrm{He}$

3

4

5

6

\author{
Camille Litty ${ }^{1,2}$, Julien Charreau ${ }^{2}$, Pierre-Henri Blard ${ }^{2}$, Raphael Pik ${ }^{2}$, Sébastien Nomade ${ }^{3}$ \\ ${ }^{1}$ Université Grenoble Alpes, CNRS, IRD, IFSTTAR, ISTerre, 38000 Grenoble, France \\ ${ }^{2}$ Centre de Recherches Pétrologiques et Géochimiques, CRPG Nancy, France \\ 3Université Versailles Saint-Quentin et Paris-Saclay, CEA Saclay, CNRS UMR 8212 Laboratoire des \\ Sciences du Climat et de l'Environnement, Gif-sur-Yvette, France
}

Corresponding authors : Dr. Camille Litty, camille.litty@univ-grenoble-alpes.fr

\title{
Abstract
}

Denudation of volcanic ocean islands creates remarkable landscapes and contributes to Earth's carbon cycle, since the chemical alteration of basalts is a $\mathrm{CO}_{2}$ sink. Because many volcanic islands have large climate gradients and relatively low variations in lithology and tectonic history, they represent excellent natural laboratories for studying climatic effects on landscape evolution. However, little is known about the control of denudation rates in ocean islands and the respective influences of climatic gradients and morphological parameters. Here, we present new measurements of long-term denudation rates from Santo Antão Island, Cape Verde $\left(17^{\circ} \mathrm{N}\right)$. In this $779 \mathrm{~km}^{2}$ island, mean annual precipitation ranges from $40 \mathrm{~mm} \cdot \mathrm{yr}^{-1}$ in the southwest to $1100 \mathrm{~mm}^{\mathrm{yr}} \mathrm{r}^{-1}$ in the north. To constrain the spatial distribution of denudation rates, we measured the cosmogenic ${ }^{3} \mathrm{He}$ concentration in river-transported pyroxene grains from 23 river bedload samples. We obtained basin wide denudation rates ranging from $2.7 \pm 0.1$ to $57.5 \pm 0.3 \mathrm{~m} / \mathrm{Ma}$. The denudation rates display a significant spatial variability, with the highest rates in catchments located in the northeast side of the island where modern precipitation are the highest and low denudation rates in the southern and western dry basins. Our study shows that precipitation is the main control on denudation and landscape development of the Santo Antão volcanic island. This study provides for the first time the spatial distribution of denudation rates across a volcanic island located in a tropical zone.

\section{Introduction}

Climate is thought to be one of the main parameters controlling denudation rates (e.g., Portenga and Bierman, 2011), which in turn impact many processes such as the building and evolution of mountain ranges (e.g., Willett, 1999; Whipple, 2009). Understanding the effects of climate on denudation rates is therefore thought to be critical, but the modality of its impact remain a matter of long-standing debate (e.g., Langbein and Schumm, 1958; DiBiase and Whipple, 2011). Conversely, denudation may also exert a strong feedback on climate at the geological time scale (e.g., Berner et al., 1983). Silicate weathering on continents consumes $\mathrm{CO}_{2}$ and releases cations $(\mathrm{Ca}, \mathrm{Mg}, \mathrm{K}, \mathrm{Na})$ to the ocean. In the ocean, $\mathrm{Ca}$ and $\mathrm{Mg}$ are then combined with $\mathrm{CO}_{3}{ }^{2-}$ and precipitated into bicarbonate, resulting 
in a net $\mathrm{CO}_{2}$ sink (e.g., Berner et al, 1983). The weathering of basaltic lithologies are thus supposed to be an efficient $\mathrm{CO}_{2}$ sink at the geological time scale (Dessert et al., 2003).

In such context, volcanic islands in tropical areas are noteworthy natural laboratories allowing the investigation of links and interactions between denudation and climatic processes for two main reasons. First, the amplitude of the denudation variations can be compared to climate only. Indeed, most of the volcanic islands often exhibit a strong climatic gradient, while tectonic and lithological forcing are comparatively negligible (Hildenbrand et al., 2008; Salvany et al., 2012; Jefferson et al., 2014). Second, according to geochemical measurements of dissolved load in rivers, the modern weathering of volcanic islands, especially in tropical areas, is especially intense (e.g., Louvat and Allègre, 1997, Jefferson et al., 2014). It may represent up to $35 \%$ of the total $\mathrm{CO}_{2}$ consumed from continental silicate weathering (Gaillardet et al., 1999) and, hence, have a large influence on long-term climate changes (Lenton and Britton, 2006).

In this general context, it is of the upmost importance to better constrain denudation rates (i.e., the sum of physical and chemical erosion) and their spatial distribution across these islands. Several studies have estimated the long-term $\left(10^{5}-10^{6} \mathrm{a}\right)$ denudation rates of several islands by reconstructing the original volcanic surfaces and then by calculating the volumes removed by erosion (Hildenbrand et al., 2008; Salvany et al., 2012; Menéndez et al., 2008; Ferrier et al., 2013; Ricci et al., 2015). This geomorphological approach relies on the postulate that the construction of the volcanoes precedes their destruction by erosion. However, these two processes can be indeed coeval, which can hamper an accurate estimate of the initial pre-erosion surface. Moreover, it is often hazardous to accurately estimate the age of the original surfaces of the volcanoes. The derived denudation rates are therefore tied to large uncertainties and must be rigorously considered as minimum values (Hildenbrand et al., 2008). Other studies have constrained modern denudation rates from direct geochemical measurements of dissolved load in rivers (Louvat and Allègre, 1997; Ferrier et al., 2013). However, these estimates remain only strictly valid over short time scales $\left(10^{1-1} 0^{2} \mathrm{a}\right)$. Therefore, the mechanisms by which volcanic islands erode at the Quaternary time scale $\left(10^{2}-10^{4}\right)$ remain largely unknown despite being a critical parameter for a comparison with long-term climate change.

Basin wide denudation rates at the Quaternary time scale can be quantified by measuring the concentration of cosmogenic nuclides in river sediment. In-situ cosmogenic nuclides are produced by the flux of secondary cosmic particles in the top few meters of Earth's surface (e.g., Granger et al., 1996). However, denudation rate measurements from cosmogenic nuclides have been mainly based on quartzrich lithologies through ${ }^{10} \mathrm{Be}$ analyses (e.g., Granger et al., 1996). On basaltic and andesitic islands, quartz is rare or inexistent, implying that ${ }^{10} \mathrm{Be}$ cannot usually be used (Blard et al., 2008). Cosmogenic ${ }^{3} \mathrm{He}$ measured in pyroxene and olivine in river bedload sediment represents a good alternative to ${ }^{10} \mathrm{Be}$ for these mafic terrains (e.g., Puchol et al., 2017). These minerals have a high helium retentivity (Blard and Pik, 2008) and their ${ }^{3} \mathrm{He}$ cosmogenic production rate is relatively well established (Balco et al., 2008). ${ }^{3} \mathrm{He}$ has been widely used for the past 30 years to date lava flows (e.g., Kurz, 1986) or to 
reconstruct continental paleoclimates (e.g., Blard et al., 2007). However, only a few studies have used cosmogenic ${ }^{3} \mathrm{He}$ to estimate denudation rates (Gayer et al., 2008, Ferrier et al., 2013, Puchol et al., 2017). Sarda et al. (1993) were the first to determine denudation rates from cosmogenic ${ }^{3} \mathrm{He}$ in a volcanic island, but this study was limited to a depth profile at one single location in La Reunion. To quantify Quaternary denudation rates Gayer et al. (2008) and Ferrier et al. (2013) measured the cosmogenic ${ }^{3} \mathrm{He}$ in river sand in Kaua'I Island (Hawaii), but both studies were limited to a single drainage basin.

In this paper, we analyze the ${ }^{3} \mathrm{He}$ cosmogenic concentrations in pyroxenes and olivines of 23 sand samples collected in 19 different modern riverbeds across the entire Santo Antão Island (Cape Verde). We hence determine, for the first time across a volcanic island, the near-whole spatial variability of denudation rates averaged over the last $10^{3}$ to $10^{5} \mathrm{ka}$.

\section{Geological and climatic settings of the Cape Verde islands and Santo Antão}

The Cape Verde archipelago $\left(4033 \mathrm{~km}^{2}\right)$ includes 10 major and several smaller islands located $\sim 600 \mathrm{~km}$ west of the African continent (Fig. 1). The development of the islands likely initiated $19 \mathrm{Ma}$ ago with tholeiitic sills that intruded the Jurassic-Cretaceous sea-floor basement (Hayes \& Rabinowitz, 1975; Duncan \& Jackson, 1977). Since 19 Ma, the volcanic activity has not migrated and has been well distributed across the islands until present (Mitchell et al., 1983; Plesner et al., 2002). The active volcanic activity is now limited to Fogo Island with the last eruption in 1995.

The climate of the Cape Verde archipelago is driven by the respective position of the subtropical high pressure of the North Atlantic (Açores anticyclone) and the Intertropical Convergence Zone (Mannaerts and Gabriels, 2000). The wet season lasts from July to October when the ITCZ, usually centered around the equator, shifts toward $10-20^{\circ} \mathrm{N}$ and brings $80 \%$ of the annual precipitation, whereas during the rest of the year, precipitation is scarce (Mannaerts and Gabriels, 2000).

Santo Antão is the northernmost and second largest island $\left(770 \mathrm{~km}^{2}\right)$ of the archipelago (Fig. 1). Its elevation ranges from 0 to $1979 \mathrm{~m}$ (Tope de Coroa), with a mean elevation of $362 \mathrm{~m}$. The relief of the island forms a major orographic barrier that creates a large precipitation gradient with annual precipitation that varies by a factor of 20-30 between the wettest northeast and the driest southwest sides (Fig. 3a). Local rainfall is also strongly dependent on elevation, with some low coastal areas having low rainfall of $0-150 \mathrm{~mm} \cdot \mathrm{yr}^{-1}$ whereas the mountain areas above $1000 \mathrm{~m}$ elevation receive $\sim 800-1000$ mm.yr ${ }^{-1}$ (Fig. 3a; Mannaerts and Gabriels, 2000). This precipitation gradient seems to have induced significant topographic heterogeneities across the island: major valleys on the north and northeast side of the island receive regular rain during the wet season and are deeply incised. In contrast, the southern part of the island receives only very irregular rain and the topography exhibits wide smooth seaward slopes preserving volcanic surfaces that are poorly incised (Fig. 3b). In addition, two deep ( $>1 \mathrm{~km})$ and large (> 5km) circular depressions are located in Tarrafal and the Cha di Morte regions (Fig. 2 and 3). These two depressions together with the deeply entrenched valley in the north provide numerous 
outcrops of the lavas that built the island and enable a good reconstruction of its volcanic history (e.g., Plesner et al., 2002; Holm et al., 2005).

On Santo Antão, the oldest lavas reported are $7.5 \mathrm{Ma}$ old altered picrites and ankaramites of the Dos Bodes formation. They can be observed in a limited area at the bottom of the Cha di Morte depression (Plesner et al., 2002; Holm et al., 2005; Fig. 2). This formation is overlain by the thick ( 800 m) 3-1 Ma old Cha di Morte formation (Fig. 2; Plesner et al., 2002). The lava flows of this formation dip toward the coast and point toward sources of magma emission located in the central part of the island. The Dos Bodes and Cha di Morte formations are usually mapped together as "Older Volcanics" by several authors (Fig. 2; Holm et al., 2005). After the emplacement of the Cha di Morte formation, between $\sim 1.4 \mathrm{Ma}$ and $0.3 \mathrm{Ma}$, other lavas flows were emplaced in other areas of the island, indicating that the recent volcanic activity was less focused and more distributed (Plenser et al., 2002, Holm et al. 2005). The Tope de Coroa volcano experienced a large flank collapse that is not yet dated and yields to the large Tarrafal circular depression. This depression was later refilled by the development of the modern Tope de Coroa stratovolcano $\sim 0.1 \mathrm{Ma}$ ago. Since $\sim 0.3 \mathrm{Ma}$, the volcanic activity of the island is mainly characterized by explosive magmatism including numerous individual scoria cones, phreatomagmatic to strombolian and several pluri-meter-thick phonolitic to tephri-phonolotic tephra deposits referenced as the Cao Grande formation (Plesner et al., 2002; Eisele et al., 2015). During this recent explosive period, several lava flows are reported in the Tope de Coroa and in the Porto Novo region.

\section{Material and methods}

\subsection{Basin average denudation rates}

Assuming isotopic steady state, meaning that the cosmogenic production of ${ }^{3} \mathrm{He}$ is balanced by the erosional loss (Lal, 1991), approximating (similarly to the spallogenic production) the two muogenic production rates at depth with two different exponential laws, then the basin average denudation rate $\left(\mathrm{cm} . \mathrm{yr}^{-1}\right)$ is given by:

$$
\bar{\varepsilon}=\sum_{x=s p, \mu_{s m}, \mu_{f m}} \frac{\overline{P_{x, 3}} \Lambda_{x}}{\rho 3_{H e}}
$$

where the subscripts $s p, \mu_{s m}$ and $\mu_{f m}$ correspond to the production by spallation, slow muon capture and fast muon processes, respectively. $\overline{P_{x, 3}}$ is the basin average in situ cosmogenic production rates at the surface $\left(\right.$ at $\left.^{-1} \mathrm{~g}^{-1}\right) . \rho$ and $\Lambda_{x}$ are the rock density $\left(\mathrm{g} \cdot \mathrm{cm}^{-3}\right)$ and the attenuation length in the rocks $\left(\mathrm{g} \cdot \mathrm{cm}^{-}\right.$ ${ }^{2}$ ) of each production pathway $\mathrm{x}$, respectively. ${ }^{3} \mathrm{He}_{\mathrm{c}}(\mathrm{at} / \mathrm{g})$ is the mean concentration of the cosmogenic ${ }^{3} \mathrm{He}$ in the river sediment. We use a basalt density of $3 \mathrm{~g} / \mathrm{cm}^{3}$ and assumed constant attenuation lengths of $160 \mathrm{~g} / \mathrm{cm}^{2}, 4320 \mathrm{~g} / \mathrm{cm}^{2}$ and $1500 \mathrm{~g} / \mathrm{cm}^{2}$ for spallation, fast muons capture and slow muons processes (e.g. Braucher et al., 2011). The basin average production rates were computed using a cell-by-cell 
approach and the SIG tool Basinga (Charreau et al., 2019) with a $30 \mathrm{~m}$ digital elevation model of the Santo Antão Island. The production rates of each of the cells of the DEM were scaled using the time dependent Lal-Stone scheme (Stone, 2000), and a reference surface production at sea level and high latitude of $122 \pm 12 \mathrm{at} \cdot \mathrm{g}^{-1} \cdot \mathrm{a}^{-1}$ has been used (world-wide mean of all calibration studies computed with the CREp calculator, Martin et al., 2017). Following DiBiase (2018), we did not apply any topographic shielding correction.

\subsection{Determination of cosmogenic ${ }^{3}$ He in pyroxenes and olivines}

The total ${ }^{3} \mathrm{He}$ concentration $\left({ }^{3} \mathrm{He}_{\mathrm{tot}}\right)$ in both pyroxenes and olivine is a three-component system (Blard and Farley, 2008) that can be written as follows:

$$
{ }^{3} \mathrm{He}_{\text {tot }}={ }^{3} \mathrm{He}_{\mathrm{c}}+{ }^{3} \mathrm{He}_{\text {mag }}+{ }^{3} \mathrm{He}_{\text {nucl }} \text { (2) }
$$

where indices $c$, mag and $n u c l$ refer to the concentration in matrix-sited cosmogenic ${ }^{3} \mathrm{He}$, the magmatic ${ }^{3} \mathrm{He}$ located in fluid and melt inclusions and the nucleogenic ${ }^{3} \mathrm{He}$ produced by neutron capture on $\mathrm{Li}$ nuclei since the eruption of the lavas, respectively.

Similarly, the total ${ }^{4} \mathrm{He}$ budget is a two-component system consisting of magmatic ${ }^{4} \mathrm{He}$ inherited in fluid and melt inclusions and matrix-sited radiogenic ${ }^{4} \mathrm{He}$ mainly produced by the decay of ${ }^{238} \mathrm{U},{ }^{235} \mathrm{U}$ and ${ }^{232} \mathrm{Th}$ since the eruption:

$$
{ }^{4} \mathrm{He}_{\text {tot }}={ }^{4} \mathrm{He}_{\mathrm{rad}}+{ }^{4} \mathrm{He}_{\mathrm{mag}} \text { (3) }
$$

Therefore, the cosmogenic ${ }^{3} \mathrm{He}_{\mathrm{c}}$ can be estimated from Eq (2) if the magmatic, the nucleogenic and the total ${ }^{3} \mathrm{He}$ can be estimated independently with accuracy and precision. The ${ }^{3} \mathrm{He}_{\text {tot }}$ can be measured by melting the sample. The nucleogenic contribution ${ }^{3} \mathrm{He}_{\text {nucl }}$ can be calculated using the mean neutron flux, the Li concentration and the eruption age of the minerals (Andrews, 1982). In practice, we used here the major and trace elements and the Li-concentrations of the phenocrysts measured at the SARM in Nancy to compute this nucleogenic component (Table A.1).

Because it can be quite variable from one aliquot to another (e.g.s Puchol et al., 2017), the magmatic ${ }^{3} \mathrm{He}_{\text {mag }}$ component is difficult to estimate. Magmatic He can be preferentially released and analyzed by in vacuo mineral crushing (Kurz, 1986). The crushing must, however, be sufficiently long to release and purge most of the trapped magmatic He. On the other hand, this crushing should not be too intense nor too long to avoid releasing the matrix sited ${ }^{3} \mathrm{He}_{\mathrm{c}}$ and/or the ${ }^{4} \mathrm{He}_{\mathrm{rad}}$ (Blard et al., 2006, 2008), nor contaminate the sample with atmospheric He (Protin et al., 2016).

In the present study, we crushed all the pyroxenes/olivines and analyzed the ${ }^{3} \mathrm{He}$ and ${ }^{4} \mathrm{He}$ concentrations extracted during this extraction step ("crush" indice). We fused in a high vacuum furnace additional uncrushed pyroxene/olivine aliquots (above $1400^{\circ} \mathrm{C}$, to ensure a complete He release), and measured the ${ }^{3} \mathrm{He}$ and ${ }^{4} \mathrm{He}$ concentrations release ("melt" indice). Then, we describe and apply two approaches to estimate the magmatic component and to calculate the ${ }^{3} \mathrm{He}$ cosmogenic concentration.

\footnotetext{
Estimation of ${ }^{3} \mathrm{He}_{\text {nucl }}$ is the same in both approaches.
} 

the latter improvements by Dunai et al. (2000) and Blard and Farley (2008), to account for the presence of ${ }^{4} \mathrm{He}_{\text {rad. }}$. In this method, the cosmogenic ${ }^{3} \mathrm{He}$ concentration is calculated as follow:

$$
{ }^{3} \mathrm{He}_{\mathrm{c}}={ }^{3} \mathrm{He}_{\text {tot }}-{ }^{3} \mathrm{He}_{\text {mag }}-{ }^{3} \mathrm{He}_{\text {nucl }}
$$$$
{ }^{3} \mathrm{He}_{\mathrm{c}}={ }^{3} \mathrm{He}_{\text {tot }}-\left[{ }^{4} \mathrm{He}_{\text {mag }} \times\left({ }^{3} \mathrm{He}_{\mathrm{mag}} /{ }^{4} \mathrm{He}_{\mathrm{mag}}\right)\right]-{ }^{3} \mathrm{He}_{\text {nucl }}
$$

$$
{ }^{3} \mathrm{He}_{\mathrm{c}}={ }^{3} \mathrm{He}_{\text {tot }}-\left[\left({ }^{4} \mathrm{He}_{\text {tot }}-{ }^{4} \mathrm{He}_{\mathrm{rad}}\right) \times\left({ }^{3} \mathrm{He}_{\mathrm{mag}} /{ }^{4} \mathrm{He}_{\mathrm{mag}}\right)-{ }^{3} \mathrm{He}_{\text {nucl }}\right.
$$

$$
{ }^{3} \mathrm{He}_{\mathrm{c}}={ }^{3} \mathrm{He} \text { melt }-\left[\left({ }^{4} \mathrm{He}_{\text {melt }}-{ }^{4} \mathrm{He}_{\text {rad }}\right) \times\left({ }^{3} \mathrm{He} /{ }^{4} \mathrm{He}\right)_{\text {crush }}\right]-{ }^{3} \mathrm{He}_{\text {nucl }}(4)
$$

The $\left({ }^{3} \mathrm{He} /{ }^{4} \mathrm{He}\right)_{\text {crush }}$ is the isotopic ratio measured during the initial crushing of the pyroxenes and olivines, which is considered as representative of the magmatic isotopic ratio.

Because pedogenesis and sediment transport induces break up of phenocrysts, we consider that the pyroxenes and olivines sampled in the riverbed loads do not bear any implanted ${ }^{4} \mathrm{He}_{\text {rad }}$ from the (U-Th) richer lava (Blard and Farley, 2008). This is justified because the implanted component is only present in the $20 \mu \mathrm{m}$ outer rim (e.g., Dunai et al., 2000). Consequently, we computed the ${ }^{4} \mathrm{He}_{\text {rad }}$ with the U-ThSm concentrations measured in the sole phenocrysts (Tables 1 and A.2). To estimate the mean ages of the lava flow, we used the geological map of List et al. (2007), and weighted each eruption age with the respective contributive size of each studied basin. Additionally, if the measured ${ }^{4} \mathrm{He}$ concentration during melting is lower than the calculated ${ }^{4} \mathrm{He}_{\text {rad, }}$, then we assume that the ${ }^{4} \mathrm{He}_{\text {mag }}$ is null in these aliquots and we only apply a correction for ${ }^{3} \mathrm{He}_{\text {nucl }}$.

The second approach assumes that the in vacuo crushing step was efficient enough to release all the magmatic ${ }^{3} \mathrm{He}$ from the aliquots and that the measured concentrations in the crushed aliquots are representative of those of the melted aliquot. In this case, Eq. (2) can be rewritten as follows:

$$
{ }^{3} \mathrm{He}_{\mathrm{c}}={ }^{3} \mathrm{He} \text { melt }-{ }^{3} \mathrm{He}_{\text {crush }}-{ }^{3} \mathrm{He}_{\text {nucl }} \text { (5) }
$$

with the indices melt and crush referring to the ${ }^{3} \mathrm{He}$ measured after melting and crushing experiments of the sample. The calculated cosmogenic ${ }^{3} \mathrm{He}$ concentrations from both approaches; Eqs. (4) and (5) are then used to estimate the average denudation rates in the different sampled river catchments on Santo Antão Island applying Eq. (1) (e.g., Granger et al., 1996).

\subsection{Sampling, treatment and analyses}

Twenty-three samples were collected at the mouth of the main rivers all around the island (Fig. 3, Table A.1). Approximately $3 \mathrm{~kg}$ of river bedload sediment was collected from each sampling site. Bulk sands were sieved under flowing water into the $0.15-0.5 \mathrm{~mm}$ granulometric fraction. A hand magnet was first used to remove a large fraction of the magnetic sediment. Then the pyroxene and olivine grains were concentrated from the sand by two magnetic separations using a Frantz device. Nearly pure pyroxene and olivine grains were then obtained by gravimetric separation in di-iodomethane (density $\sim 3.3 \mathrm{~g} \mathrm{~cm}^{-3}$ ). After washing in diethyl ether and drying, the grains were cleaned in an ultrasonic 
bath of deionized water, and then acetone, for $10 \mathrm{~min}$ each, to remove any impurities resulting from dust. After drying, all grains with attached lava fragments were removed and discarded by handpicking under a binocular microscope. We chose to work mainly on pyroxenes because they were more abundant in our samples and thus easier to separate. Nevertheless, when olivines were present in some samples, we also analyzed mixed olivine/pyroxene aliquots. To measure the total ${ }^{3} \mathrm{He}$ and ${ }^{4} \mathrm{He}$ concentrations, grain aliquots were wrapped in copper foils and fused at $1350^{\circ} \mathrm{C}$ for $15 \mathrm{~min}$. High temperature extractions were performed with the full metal induction furnace designed at CRPG (Zimmermann et al., 2012). After extraction, the gas was purified using activated charcoal at $-196^{\circ} \mathrm{C}$ and with hot $\left(400^{\circ} \mathrm{C}\right.$ and $\left.600^{\circ} \mathrm{C}\right)$ and ambient temperature $\left(21^{\circ} \mathrm{C}\right)$ titanium sponge getters. A complete description of the furnace and the purification line can be found in Zimmermann et al. (2012). Helium was analyzed on a GV HELIX Split Flight Tube dual collector mass spectrometer. The instrument sensitivity was determined using the HESJ standard (Matsuda et al., 2002) whose certified ${ }^{3} \mathrm{He} /{ }^{4} \mathrm{He}$ ratio is $20.63 \pm 0.10$ $\mathrm{Ra}\left(\mathrm{Ra}=1.384 \times 10^{-6}\right.$ being the atmospheric ${ }^{3} \mathrm{He} /{ }^{4} \mathrm{He}$ ratio $)$. To measure the $\mathrm{He}$ mag concentration, invacuo crushing extractions were performed on additional aliquots with a soft iron slug activated by external solenoids ( $5 \mathrm{~min}$ at 100 strokes/min). After a first measurement, to optimize the release of all the $\mathrm{He}_{\mathrm{mag}}$, second crushing extractions of the same aliquot were performed. In the first approach, the mean value of the two crushing experiments was used to calculate the $\left({ }^{3} \mathrm{He} /{ }^{4} \mathrm{He}\right)_{\text {crush }}$ ratios (i.e., the magmatic ${ }^{3} \mathrm{He} /{ }^{4} \mathrm{He}$ ratio). In the second approach, the sum of the two crushing experiments has been used to compute the ${ }^{3} \mathrm{He}_{\mathrm{c}}$ as this approach assumes that the crushing extracts the whole magmatic He. Finally, to test the reproducibility of the methods, nine samples have been replicated and analyzed after high temperature extraction. For these replicates, magmatic corrections were performed using the same He results from in-vacuo crushing extraction.

\section{Results}

Information about samples and catchment metrics are given in supplementary Table A.1. Annual precipitation rates have been estimated from the TRMM model with $20 \%$ of uncertainties and gradient information have been extracted from a $30 \mathrm{~m}$ resolution DEM (Table A.1). Helium results of the pyroxenes/olivines crushing are presented in Table A.1. Major and trace element concentrations used to calculate the ${ }^{4} \mathrm{He}_{\mathrm{rad}}$ and ${ }^{3} \mathrm{He}_{\text {nucl }}$ components are given in supplementary Table A.2. Results of high temperature extractions and calculated ${ }^{3} \mathrm{He}_{\mathrm{c}}$ concentration and denudation rates are presented in Table 1.

Mean ${ }^{4} \mathrm{He}$ and ${ }^{3} \mathrm{He}$ blanks during heating extraction were $(7.3 \pm 0.3) \times 10^{-15} \mathrm{~mol}$ and $(1.24 \pm$ $0.2) \times 10^{-19} \mathrm{~mol}$, respectively. Repeated measures after sample heating extraction always yielded $\mathrm{He}$ concentrations in the blank range, indicating that the extraction was complete after the first heating step. Mean ${ }^{4} \mathrm{He}$ and ${ }^{3} \mathrm{He}$ sample values during heating extraction before blank correction were $(1.10 \pm 0.03)$ $\times 10^{-12} \mathrm{~mol}$ and $(4.2 \pm 0.2) \times 10^{-18} \mathrm{~mol}$, respectively, one to three orders of magnitude higher than the 
measured blank concentrations. This implies that blanks do not represent a significant source of uncertainty. Mean ${ }^{4} \mathrm{He}$ and ${ }^{3} \mathrm{He}$ blanks measured from the crushing device (with the slug moving) were $(8.6 \pm 0.4) \times 10^{-15} \mathrm{~mol}$ and $(1.4 \pm 0.1) \times 10^{-19} \mathrm{~mol}$, respectively. Mean ${ }^{4} \mathrm{He}$ and ${ }^{3} \mathrm{He}$ sample values for the crushing experiments before blank correction were $(5.8 \pm 1.5) \times 10^{-14} \mathrm{~mol}$ and $(6.5 \pm 1.7) \times 10^{-19}$ mol, respectively. Blanks therefore represent 10 to $20 \%$ of the crushing concentrations. The calculated concentrations have been then corrected with the mean blank values.

This corresponds to total ${ }^{4} \mathrm{He}$ and ${ }^{3} \mathrm{He}$ concentrations measured after heating experiments ranging between $(13 \pm 1) \times 10^{10}$ and $(27 \pm 1) \times 10^{11}$ at/g and between $(22 \pm 3) \times 10^{5}$ and $(29 \pm 1.3) \times 10^{6}$ at/g, respectively (Table 1). The magmatic ${ }^{4} \mathrm{He}$ and ${ }^{3} \mathrm{He}$ concentrations measured after the first in-vacuo crushing extractions range between $(6.3 \pm 0.1) \times 10^{9}$ and $(2.6 \pm 0.2) \times 10^{11}$ at $/ \mathrm{g}$ and between $(1.9 \pm 0.1)$ $\times 10^{4}$ and $(8.8 \pm 0.4) \times 10^{6}$ at $/ \mathrm{g}$, respectively (Table A.1). Corresponding ${ }^{3} \mathrm{He} /{ }^{4} \mathrm{He}$ ratios measured by crushing range between $2 \pm 14 \mathrm{Ra}$ and $15 \pm 10$ with a weighted mean of $12.2 \pm 0.3 \mathrm{Ra}\left(\mathrm{Ra}=1.384 \times 10^{-6}\right.$ being the atmospheric ${ }^{3} \mathrm{He} /{ }^{4} \mathrm{He}$ ratio). Second in-vacuo crushing extractions show similar results and, when summed with the first crushing, returned total magmatic values that range between $(6.3 \pm 0.1) \times$ $10^{9}$ and $(5.8 \pm 0.2) \times 10^{11}$ at $/ \mathrm{g}$ and between $(1.9 \pm 0.1) \pm 10^{4}$ and $(1.1 \pm 0.06) \times 10^{7}$ at $/ \mathrm{g}$ for ${ }^{4} \mathrm{He}$ and ${ }^{3} \mathrm{He}$, respectively. The isotopic ratios of the two crushing together range between $2 \pm 14 \mathrm{Ra}$ and $14.1 \pm 0.9$ $\mathrm{Ra}$, with a weighted mean of $11.8 \pm 0.4 \mathrm{Ra}$. However, some samples have not been measured for a second in-vacuo crushing extraction.

With the first approach, calculated cosmogenic ${ }^{3} \mathrm{He}$ concentrations range between $(2.1 \pm 1.4) \times$ $10^{6}$ at $/ \mathrm{g}$ and $(2.0 \pm 0.17) \times 10^{7}$ at $/ \mathrm{g}$ (Table 1). Eight aliquots show ${ }^{3} \mathrm{He}_{\mathrm{mag}}>{ }^{3} \mathrm{He}_{\text {melt }}$ therefore yielding null cosmogenic ${ }^{3} \mathrm{He}_{\mathrm{c}}$ concentrations. The second approach leads to ${ }^{3} \mathrm{He}_{\mathrm{c}}$ concentrations ranging between $(2.0 \pm 0.3) \times 10^{6}$ and $(2.3 \pm 0.1) \times 10^{7}$ at $/ g$. Importantly, the two approaches yield ${ }^{3} \mathrm{He}_{\mathrm{c}}$ concentrations and denudation rates that are close to the 1:1 line for most of the samples (Fig. $4 \mathrm{a}$ and b), indicating that the choice of the correction procedure for the non-cosmogenic ${ }^{3} \mathrm{He}$ components is not a significant source of uncertainty. Based on these cosmogenic ${ }^{3} \mathrm{He}$ concentrations, we determined the denudation rates of 23 samples in 19 main catchments all across the Santo Antão Island. Considering the two approaches, and ignoring the few samples that yielded null-cosmogenic ${ }^{3} \mathrm{He}$ concentrations, denudation rates show a variability across the island, from $2.7 \pm 0.1 \mathrm{~m} / \mathrm{Ma}$ (CV18-01) to $58 \pm 4 \mathrm{~m} / \mathrm{Ma}$ (CV18-20), with a mean denudation rate over the studied catchments of $18.0 \pm 5.2 \mathrm{~m} / \mathrm{Ma}$. Finally, the nine replicated measurements are compatible within analytical uncertainties (Fig. 5a, b,c). For denudation rates lower than $15 \mathrm{~m} / \mathrm{Ma}$, the correlation between replicates is robust and is not dependent on the approach (Fig. $5 \mathrm{~d} ; \mathrm{R}^{2}=0.76$, $\mathrm{p}$-value $\left.=0.002\right)$.

\section{Discussion}

5.1 Reliability of the calculated cosmogenic ${ }^{3} H e$ concentrations and derived denudation rates 
The reconstruction of the ${ }^{3} \mathrm{He}_{\mathrm{c}}$ concentrations relies on several assumptions and corrections that must be considered. First, the two approaches give similar results, which suggest that the concentration in cosmogenic ${ }^{3} \mathrm{He}$ has been accurately quantified. However, when looking in detail, the ${ }^{3} \mathrm{He}_{\mathrm{c}}$ concentrations obtained with the second approach are lower by $\sim 10$ to $20 \%$ compared to those of the first approach, for most of the samples (Fig. $4 \mathrm{a}$ ), leading to $\sim 10$ to $20 \%$ higher denudation rates (Fig. $4 \mathrm{~b})$. The first approach depends on the accuracy of the ${ }^{4} \mathrm{He}$ radiogenic and the magmatic $\left({ }^{3} \mathrm{He} /{ }^{4} \mathrm{He}\right)$ estimates. The assumption that the implanted radiogenic ${ }^{4} \mathrm{He}$ from the (U-Th) richer lava can be neglected is supported by the fact that, if it is considered, computed radiogenic ${ }^{4} \mathrm{He}$ are larger than the total ${ }^{4} \mathrm{He}$ measured in almost $90 \%$ of the analyzed aliquots. On the other hand, the lower ${ }^{3} \mathrm{He}_{\mathrm{c}}$ concentrations obtained with the first approach could suggest an underestimate of the ${ }^{4} \mathrm{He}_{\text {rad. }}$. This could result from an underestimate of the eruption age of the bedrock material. Rivers may actually erode more efficiently the older lithologies than the younger ones. Alternatively, older rocks are porphyritic and probably contain more pyroxenes than the younger ones. However, we carefully estimated the mean bedrock ages in each basin, propagating high uncertainties considering the age distributions within a given basin (from 10 to $93 \%$, average $=60 \%$; Table A.1). For that reason, the first approach yields higher uncertainties (mean $1 \sigma$ error of $20 \%$ ) than the second one (mean $1 \sigma$ error of $10 \%$ ). Second, the lower cosmogenic ${ }^{3} \mathrm{He}$ concentrations calculated with the first approach compared to the second may also suggest an overestimation of $\left({ }^{3} \mathrm{He} /{ }^{4} \mathrm{He}\right)_{\mathrm{mag}}$ ratio from the crushing experiments. Too intense crushing could have partially released the ${ }^{3} \mathrm{He}_{\mathrm{c}}$ trapped in the crystal lattice (Blard et al., 2006, 2008). Moreover, the good reproducibility between the nine replicates suggests that merging hundreds of grains in each aliquot seems sufficient to average the ${ }^{3} \mathrm{He}_{\mathrm{c}}$ concentration, despite possible spatial variability of the denudation in the watershed (Puchol et al., 2017). Samples yielding denudation rates above $\sim 15$ $\mathrm{m} / \mathrm{Ma}$ display an increase of the inter-aliquot scatter, with up to $57 \%$ of differences between the replicates (Fig. 5c). This observation suggests that, in Santo Antão Island, $\sim 15 \mathrm{~m} / \mathrm{Ma}$ seems to be a threshold value, above which denudation rates can only be measured with lower accuracy and precision. This threshold is directly controlled by the cosmogenic/magmatic ratio, as well as by the amount of radiogenic ${ }^{4} \mathrm{He}$. It may thus vary from one geological setting to another and it may represent a significant limitation, particularly in catchments where denudation rates are high ( $>10 \mathrm{~m} / \mathrm{Ma}$; Puchol et al., 2017). Foeken et al. (2012) have calibrated the local ${ }^{3} \mathrm{He}$ cosmogenic production rate in the nearby Fogo Island to $75.6 \pm 7.0$ at. $\mathrm{g}^{-1} \cdot \mathrm{yr}^{-1}$ in olivine and $70.1 \pm 2.9$ at. $\mathrm{g}^{-1} \cdot \mathrm{yr}^{-1}$ in pyroxene. These values are significantly lower than other ${ }^{3} \mathrm{He}$ production rates found elsewhere in the world and the reference surface production at sea level and high latitude of $122 \pm 12 \mathrm{at}^{-1} \mathrm{~g}^{-1} \mathrm{yr}^{-1}$ (Martin et al., 2017) that we use in our calculations. Foeken et al. (2012) explained this discrepancy by geomagnetic field strength spatial variability. Considering these local production rates would decrease all our Cape Verde denudation rate values but would not change their relative spatial variations. 
In summary, we conclude that we accurately measured and estimated the different $\mathrm{He}$ components and that the two approaches provide reliable estimates of the cosmogenic ${ }^{3} \mathrm{He}_{\mathrm{c}}$ concentration. Because the uncertainties associated to the second approach are lower than those of the first one, and because both approaches produce results that are identical within uncertainties, we restrain the following discussion to the denudation rates derived from the second approach.

\subsection{Denudation rates variability in Santo Antão}

The studied hydrological basins of Santo Antão are characterized by a broad range of basinaveraged denudation rates, ranging between $\sim 3$ and $\sim 60 \mathrm{~m} / \mathrm{Ma}$ and therefore varying by a factor of 20 across the island (Fig. 6; Table 1). The basins in the south and west sides of the island display the lower calculated denudation rates ranging from $\sim 3$ and $\sim 20 \mathrm{~m} / \mathrm{Ma}$. One sample (CV18-26) located in the south of the island but shows a relatively high denudation rate $(26.1 \pm 5.4 \mathrm{~m} / \mathrm{Ma}$ and $36.6 \pm 4.4 \mathrm{~m} / \mathrm{Ma}$ with the first and second approach respectively) and compared to the other southern basins seems to be an outlier that is not representative of this subregion. The northern basins are characterized by a gradient of the denudation rates from the southeast to the northwest. Finally, the region of the Cha di Morte displays the highest denudation rates of the island, with values reaching $\sim 60 \mathrm{~m} / \mathrm{Ma}$ (Fig. 6). These denudation rates inferred from ${ }^{3} \mathrm{He}_{\mathrm{c}}$ are averaged over characteristic timescales $\left(\mathrm{T}_{\text {int }}=(\Lambda / \rho) / \varepsilon\right)$. In Santo Antão, the integrated timescale of these denudation rates ranges from $\sim 10 \mathrm{ka}$ for the fastest eroded basins in the north, to $\sim 200 \mathrm{ka}$ for the southern basins, with a mean value of $\sim 50 \mathrm{ka}$ for the island (Table 1). However, in the south side of the island, the calculated integration time is in some places higher than the age of the rocks. This suggests that the southern side could exhibit even lower denudation rates than the calculated rates. This variability of long-term denudation rates variability across Santo Antão seem to correlate with the modern precipitation pattern on the island. Basins located in the northeast and receiving relatively high precipitation are characterized by the highest denudation rates. Basins located in the south receiving the lowest annual precipitation rates of the island yield the lowest denudation rates (Fig. 3a and 6). This observation is consistent with the study of Ferrier et al. (2013): by reconstructing the eroded volume in 24 basins across Kaua'I in Hawaii, these authors found that long-term (Ma) denudation rates on the island are correlated with modern annual precipitation.

However, given the typical integration time of our cosmogenic ${ }^{3} \mathrm{He}$-derived denudation rates of $53 \mathrm{ka}$, spatial patterns in precipitation rates may have been different in the past, meaning that the denudation rates we have measured could result from superimposed successive climatic settings. In Santo Antão, the trade winds have been stable since at least the last glacial maximum, 20 ka (Rognon et al., 1996). Another study even suggests that trade winds have been present over the last 140 ka (Hooghiemstra, 1989). Such timescales are similar to, or longer than, the integration time of the cosmogenic ${ }^{3} \mathrm{He}-$ derived denudation rates. This created a stable mean gradient of precipitation that caused one side of the island to erode at higher rates than the other. Moreover, during this time span the volcanic activity that could 
have reshaped and reconstructed the surface of the islands was relatively limited (Plesner et al., 2002). Therefore, climatic conditions can explain the spatial variations of the long-term denudation rates across the island.

On the other hand, the topographic patterns also strongly vary across the island and is also in apparent correlation with the variability of denudation rates. Steeply sloping valleys are located in the northeast side of the island, in the Tarrafal and Cha di Morte depressions where denudation rates are high ( $>40 \mathrm{~m} / \mathrm{Ma}$ ). The southern side of the island presents relatively low denudation rates, a relatively smooth morphology and low slope angles (Fig. 7). Gayer et al. (2008) also explained variations in cosmogenic ${ }^{3} \mathrm{He}$ measured in 26 samples across the Waimea basin in Kaua'I (Hawaii) by a non-linear link between denudation rates and hillslope gradient. Yet the topography of the island could be inherited from its volcanic construction (Lahitte et al., 2012) independently from the precipitation pattern.

To better explore and separate the correlation existing between denudation rates, precipitation rates and slopes, we performed a principal component analysis (PCA) using XLSTAT software (Jolliffe, 2002). The PCA for the mean annual precipitation, mean and maximum slopes in the catchments resulted in a distance biplot of the first two principal axes shown in Fig. 8. The first and second axis explained $74.6 \%$ and $18.6 \%$ of the variance, respectively. Samples were grouped in five clusters according to their denudation rates (Fig. 8). The striking feature of this PCA is that basins with low denudation rates $(<10$ $\mathrm{m} / \mathrm{Ma}$ ) present both low mean precipitation and low mean and maximum slopes at the same time. Basins with denudation rates between 10 and $40 \mathrm{~m} / \mathrm{Ma}$ display both relatively high mean precipitation and relatively high slopes in the catchments. The sample CV18-26, which seemed to be an outlier from a visual point of view, is also an outlier here as it does not belong to the right part of the graph (Fig. 8). Past studies have suggested strong coupling and feedbacks between climate, denudation and landscape evolution in active mountain ranges (e.g., Willet, 1999; Whipple, 2009). This study reinforces this idea and moreover suggests that these coupling and feedback processes also exist on volcanic islands, and that these forcing are not necessarily linear. In Santo Antão, the precipitation patterns over time control the potential for physical erosion and weathering (Jefferson et al., 2014). The spatial variability of denudation rates influences the differential evolution of the morphology over the island, initiating a probable positive feedback: high precipitation led to higher denudation rates on the northeast side of the island, allowing for the creation of deeply incised basins with high slope angles, high drainage density and fluvial valleys that penetrate inland to the central part of the island, amplifying the local denudation. In contrast, low precipitation leading to relatively low denudation rates on the south side of the island causes the formation of weakly dissected basins with low slopes, little tributary development and lack of deep valleys. Over the long term, the morphology of the island may thus have enhanced the denudation variability through positive feedbacks with the slopes where high slopes contributing to increase the potential for fluvial erosion. Therefore, topography on the island seems to be controlled by denudation rates rather than the contrary, at least at the initial stage of the island history. Moreover, climatic conditions seem to be the predominant process that has shaped the morphology of Santo Antão. 
However, the highest denudation rates of the island $(>40 \mathrm{~m} / \mathrm{Ma})$ are correlated with high precipitation rates, but are not necessarily associated with the highest slopes, suggesting that other parameters, such as geological properties, may also play a role.

Similarly, denudation rates estimated for CV18-19 and CV18-20, which are two of the highest values of the island, but located in the lee side of the island, can also result from other causes. (i) The valley bottom of the Cha di Morte is filled by alluvial conglomeratic deposits that are incised by modern streams. Sediments that have been sampled can possibly be recycled material from paleo conglomeratic deposits. They therefore record paleo-denudation rates that can differ from the modern ones. Additionally, these conglomerates are also probably characterized by a higher erodibility than pristine lava flow basalts. (ii) The Cha di Morte depression has been interpreted as being close to the source of the older volcanic magma and numerous dike and sills are intruding into the Dos Bodes and Cha di Morte formations (Holm et al. 2005). Dikes can significantly influence basin dissection by compartmentalizing the volcanic structure into individual blocks and increase water infiltration (Hildenbrand et al., 2005). Thus, in the Cha di Morte depression, the relative high denudation rates can also possibly be caused by an increase of the chemical alteration or be associated with physical erosion through mass-wasting of individual blocks.

\subsection{Denudation rates in other volcanic islands in the world}

In Cape Verde, our denudation rates results obtained for Santo Antão, are ranging between $\sim 3$ and $60 \mathrm{~m} / \mathrm{Ma}$ and are comparable to those calculated on other volcanic islands characterized by different climatic patterns. In Kaua'I Island, Hawaii, Ferrier et al (2013) computed denudation rates based on eroded volume that range between 3 and $112 \mathrm{~m} / \mathrm{Ma}$. For the same island, Gayer et al (2008) proposed a denudation rate of $56 \mathrm{~m} / \mathrm{Ma}$ from cosmogenic ${ }^{3} \mathrm{He}$ measured in 26 samples across the Waimea basin. In Gran Canaria, Canary Islands, denudation rates based on eroded volume range between 0.1 and 240 m/Ma (Menéndez et al., 2008). One extreme value reaches $975 \mathrm{~m} / \mathrm{Ma}$, however, it has been measured in a small basin of $2.3 \mathrm{~km}^{2}$. We decided to discard this value as well as 14 other denudation rates that have been computed in basins smaller than $5 \mathrm{~km}^{2}$. This avoids most of the outliers that seem to be related to local effects related to small eroded volumes in modest catchments. Finally, in Tahiti-Nui, in French Polynesia, Hildebrand et al. (2008) calculated denudation rates between 72 and $2700 \mathrm{~m} / \mathrm{Ma}$. Results from the different volcanic islands show significant differences in the range and absolute value of the observed denudation rates. Despite the different techniques used to infer denudation rates, previous studies and our study can be directly compared as all techniques measure both the mechanical and chemical erosion (Kirchner et al., 2006; Ferrier et al., 2013). Remarkably, we observe a logarithmic correlation between the Quaternary denudation rates and the mean annual precipitation rates when considering the data of the four islands $\left(\mathrm{R}^{2}=0.63\right.$, $\mathrm{p}$-value $<0.001$; Fig. 9). Although these different islands have variable volcanic morphologies and lithology, resulting from different geodynamic contexts, climatic conditions seem to be a predominant control on the denudation rates, and therefore, 
on landscape evolution not only in Santo Antão but also in other volcanic islands in general. Our results demonstrate the strong coupling through which climate influences the variability of denudation and show how climate acts to shape the landscape of volcanic islands.

\section{Conclusion}

We accurately measured long-term (over $10 \mathrm{ka}$ to $200 \mathrm{ka}$ timescale) denudation rates from cosmogenic ${ }^{3} \mathrm{He}$ in pyroxene from 23 river bedload samples in Santo Antão Island. The calculation of the long-term denudation rates allows the reconstruction of a volcanic island landscape and landform history in response to a contrasted climate. Exposed to the trade winds and associated relatively heavy rainfall, the northeast part of the island exhibits high denudation rates and deeply incised basins. The southern part of the island that currently receives low precipitation displays low denudation rates and gently southward dipping slopes. Accordingly, the denudation rates and the morphological evolution of the Santo Antão Island is probably primarily controlled by climatic processes. After comparison with previously published denudation rates from other islands, our data shows that the large climatic gradients existing on volcanic ocean islands have a predominant role on their landscape evolution. Our data represent additional inputs for construction of the global database of long-term denudation rates affecting volcanoes within tropical settings. The development of such database is key for better quantifying chemical and mechanical erosion processes in tropical environments.

\section{Acknowledgments}

The manuscript has been read by all authors, who have approved the content and agree to its publication. This study was supported by the INSU-CNRS SYSTER. We thank Emmanuel Davy for the mineralogical separation of the samples and Laurent Zimmerman for his assistance and help during $\mathrm{He}$ measurements.

\section{References}

Andrews, J. N., and R. L. F. Kay. 1982. Natural production of tritium in permeable rocks." Nature 298 (5872), 361-363.

Balco, G., Stone, J.O., Lifton, N.A., and Dunai, T.J., 2008, A complete and easily accessible means of calculating surface exposure ages or erosion rates from 10Be and 26Al measurements: Quaternary Geochronology 3 (3), 174195, doi:10.1016/j.quageo.2007.12.001. 
Berner, R.A., Lasaga, A.C., and Garrels, R.M., 1983, The carbonate-silicate geochemical cycle and its effect on atmospheric carbon dioxide over the last 100 million years: American Journal of Science 283, 641-683, doi: 10 .2475 /ajs .283 .7 .641

Blard, P.-H., Pik, R., Lavé, J., Bourlès, D., Burnard, P.G., Yokochi, R., Marty, B., Trusdell, F., 2006. Cosmogenic 3 He production rates revisited from evidences of grain size dependent release of matrix sited helium. Earth Planet. Science Letter 247, 222-234.

Blard, P. H., Lavé, J., Pik, R., Wagnon, P., Bourlès, D., 2007. Persistence of full glacial conditions in the central Pacific until 15,000 years ago. Nature 449 (7162), 591.

Blard, P. H., Farley, K. A., 2008. The influence of radiogenic $4 \mathrm{He}$ on cosmogenic $3 \mathrm{He}$ determinations in volcanic olivine and pyroxene. Earth and Planetary Science Letters 276 (1-2), 20-29.

Blard, P.-H., \& Pik, R., 2008. An alternative isochron method for measuring cosmogenic $3 \mathrm{He}$ in lava flows Chem. Geol. 251, 20-32

Blard, P.-H., Puchol, N., Farley, K.A., 2008. Constraints on the loss of matrix-sited helium during vacuum crushing of mafic phenocrysts. Geochim. Cosmochim. Acta, 72, 3788-3803.

Blard, P. H., Bourles, D., Pik, R., \& Lavé, J., 2008. In situ cosmogenic 10Be in olivines and pyroxenes. Quaternary Geochronology 3(3), 196-205.

Charreau, J., Blard, P. H., Zumaque, J., Martin, L. C., Delobel, T., \& Szafran, L., 2019. Basinga: A cell- by- cell GIS toolbox for computing basin average scaling factors, cosmogenic production rates and denudation rates. Earth Surface Processes and Landforms 44 (12), 2349-2365.

Dessert, C., Dupré, B., Gaillardet, J., François, L. M., \& Allegre, C. J., 2003. Basalt weathering laws and the impact of basalt weathering on the global carbon cycle. Chemical Geology 202 (3-4), 257-273.

DiBiase, R. A., \& Whipple, K. X., 2011. The influence of erosion thresholds and runoff variability on the relationships among topography, climate, and erosion rate. Journal of Geophysical Research: Earth Surface 116(F4).

DiBiase, R. A., 2018. Increasing vertical attenuation length of cosmogenic nuclide production on steep slopes negates topographic shielding corrections for catchment erosion rates. Earth Surface Dynamics 6(4).

Dunai, T., 2000. Scaling factors for production rates of in situ produced cosmogenic nuclides: A critical reevaluation: Earth and Planetary Science Letters 176 (1), 157-169, doi:10.1016/S0012-821X(99)00310-6.

Duncan, R. A. \& Jackson, E. D., 1977. Geochronology of basaltic rocks recovered by DSDP Leg 41, Eastern Atlantic Ocean. In: Lancelot, Y., Seibold, E., et al. (eds) Initial Report of the Deep Sea Drilling Project, 41, Washington, DC: US Government Printing Office, 1113-1118. 

Covariation of climate and long-term erosion rates across a steep rainfall gradient on the Hawaiian island of Kaua 'i. Bulletin 125 (7-8), 1146-1163.

502

503

Foeken, J. P., Stuart, F. M., \& Mark, D. F., 2012. Long-term low latitude cosmogenic 3He production rate determined from a 126 ka basalt from Fogo, Cape Verdes. Earth and Planetary Science Letters 359, 14-25.

Gaillardet J., Dupre B., Louvat P., Allegre C.J., 1999. Global silicate weathering and CO2 consumption rates deduced from the chemistry of large rivers. Chemical Geology, 159 (1-4), 3-30

Gayer E., Mukhopadhyay S., Meade B.J., 2008. Spatial variability of erosion rates inferred from the frequency distribution of cosmogenic 3He in olivines from Hawaiian river sediments.Earth Planet. Sci. Lett. 266, 303-315.

Granger, D. E., Kirchner, J. W., \& Finkel, R., 1996. Spatially averaged long-term erosion rates measured from in situ-produced cosmogenic nuclides in alluvial sediment. The Journal of Geology 104 (3), 249-257.

Hayes, D. E., \& Rabinowitz, P. D., 1975. Mesozoic magnetic lineations and the magnetic quiet zone off northwest Africa. Earth and Planetary Science Letters 28 (2), 105-115.

Hildenbrand, A., Gillot, P.Y., Marlin, C., 2008. Geomorphological study of long-term erosion on a tropical volcanic ocean island: Tahiti-Nui (French Polynesia), Geomorphology 93 (3-4), 460-481, doi:10.1016/j.geomorph.2007.03.012.

Hooghiemstra, H., 1989. Variations of the NW African trade wind regime during the last 140000 years: changes in pollen flux evidenced by marine sediment records. In Paleoclimatology and paleometeorology: modern and past patterns of global atmospheric transport. Springer, Dordrecht. 733-770.

Holm, P. M., Wilson, J. R., Christensen, B. P., Hansen, L., Hansen, S. L., Hein, K. M., Mortensen, A. K., Pederson, R., Plesner, S., Runge, M. K., 2005. Sampling the Cape Verde mantle plume: evolution of melt compositions on Santo Antão, Cape Verde Islands. Journal of Petrology 47 (1), 145-189.

Jefferson, A. J., Ferrier, K. L., Perron, J. T., Ramalho, R., 2014. Controls on the hydrological and topographic evolution of shield volcanoes and volcanic ocean islands. The Galapagos: A natural laboratory for the Earth Sciences 204, 185-213.

Jolliffe, I.T., 2002. Principal Component Analysis, Series: Springer Series in Statistics, 2nd ed., Springer, NY, XXIX, 487 p. 28 illus. ISBN 978-0-387-95442-4.

Kirchner, J. W., Riebe, C. S., Ferrier, K. L., Finkel, R. C., 2006. Cosmogenic nuclide methods for measuring longterm rates of physical erosion and chemical weathering. Journal of Geochemical Exploration 88 (1-3), 296-299.

Kurz, M.D., 1986. Cosmogenic helium in a terrestrial igneous rock: Nature 320, 435-439, doi:10.1038/320435a0.

Lahitte, P., Samper, A., Quidelleur, X., 2012. DEM-based reconstruction of southern Basse-Terre volcanoes (Guadeloupe archipelago, FWI): Contribution to the Lesser Antilles Arc construction rates and magma production. Geomorphology 136 (1), 148-164. 

and Planetary Science Letters 104 (2-4), 424-439.

Langbein, W. B., \& Schumm, S. A., 1958. Yield of sediment in relation to mean annual precipitation. Eos, Transactions American Geophysical Union 39 (6), 1076-1084. CO2 perturbations. Global Biogeochemical Cycles 20 (3), GB3009.

538 List, F. K., Klitzsch, E., Kusserow, H., Munier, K., Munier, C., Levenhagen, J., 2007. Cape Verde Islands: Santo 539 Antão, São Vicente, Sal, Fogo, Thematic Maps, Geology. Amt Für Geoinformationsweser der Bundeswehr 540 (AGeoBW)/Geoinformation Office of the German Armed Forces. geochemistry: basalt weathering and mass budget between chemical and mechanical erosions. Geochimica et 212. Y., 2002. The 3He/4He ratio of the new internal He Standard of Japan (HESJ). Geochemical Journal 36 (2), 191 195.

Menéndez, I., Silva, P. G., Martín-Betancor, M., Pérez-Torrado, F. J., Guillou, H., Scaillet, S., 2008. Fluvial dissection, isostatic uplift, and geomorphological evolution of volcanic islands (Gran Canaria, Canary Islands, Spain). Geomorphology 102 (1), 189-203.

Mitchell, J. G., Le Bas, M. J., Zielonka, J., Furnes, H., 1983. On dating the magmatism of Maio, Cape Verde islands. Earth and Planetary Science Letters 64 (1), 61-76.

Plesner, S., Holm, P. M., Wilson, J. R., 2002. 40Ar/39Ar geochronology of Santo Antao, Cape Verde Islands. 4-10.

Protin, M., Blard, P. H., Marrocchi, Y., Mathon, F., 2016. Irreversible adsorption of atmospheric helium on olivine: A lobster pot analogy. Geochimica et Cosmochimica Acta 179, 76-88. Ethiopian river sands of detrital pyroxenes: Impact on denudation rate determinations. Chemical Geology 448, 13 25. 
Ricci, J., Lahitte, P., Quidelleur, X., 2015. Construction and destruction rates of volcanoes within tropical environment: Examples from the Basse-Terre Island (Guadeloupe, Lesser Antilles). Geomorphology 228, 597607.

Salvany, T., Lahitte, P., Nativel, P., Gillot, P. Y., 2012. Geomorphic evolution of the Piton des Neiges volcano (Réunion Island, Indian Ocean): competition between volcanic construction and erosion since $1.4 \mathrm{Ma}$. Geomorphology $136(1), 132-147$.

Sarda, P., Staudacher, T., Allègre, C. J., Lecomte, A., 1993. Cosmogenic neon and helium at Réunion: measurement of erosion rate. Earth and Planetary Science Letters 119 (3), 405-417.

Willett, S. D., 1999. Orogeny and orography: The effects of erosion on the structure of mountain belts. Journal of Geophysical Research: Solid Earth 104 (B12), 28957-28981.

Whipple, K.X., 2009, The influence of climate on the tectonic evolution of mountain belts. Nature Geoscience 2, 97-104, doi: 10.1038/ngeo413.

Zimmermann, L., Blard, P. H., Burnard, P., Medynski, S., Pik, R., Puchol, N., 2012. A new single vacuum furnace design for cosmogenic 3He dating. Geostandards and Geoanalytical Research 36 (2), 121-129.

\section{Figure captions}

Figure 1. Overview of the Cape Verde islands and ASTER satellite images of Santo Antão Island.

Figure 2. Simplified geological map of Santo Antão modified from List et al. (2007).

Fig 3. a. Precipitation and elevation maps over Santo Antão Island from TRMM. The black arrows show the main direction of the wind. b. Photograph of the dry region of Tarrafal on the southwest side of the island. c. Photograph of the wetter valley of the Ribeira on the northeast side of the island.

Fig 4: a. ${ }^{3} \mathrm{He}_{\mathrm{c}}$ calculated with the first approach (Eq. 4) versus the ${ }^{3} \mathrm{He}_{\mathrm{c}}$ calculated with the second approach (Eq. 5). b. Denudation rates calculation from the first approach versus the denudation rates calculation from the second approach. The grey band represents the single prediction band of the one standard deviation of the correlation trend in red. 
Figure 5: Comparison of the replicate measures of the denudation rates. a. Comparison of the replicates of the denudation rates calculated with the first approach. b. Comparison of the replicates of the denudation rates calculated with the second approach. c. Comparison of the replicates of the denudation rates calculated with the two approaches together. D. Zoom of the Fig. 5c showing the best reproducibility of the measurements for denudation rates lower than $\sim 15 \mathrm{~m} / \mathrm{Ma}$.

602

Figure 6: Spatial variation of the denudation rates on Santo Antão Island.

604

605

Figure 7: Map of the slope distribution on Santo Antão and hillshade map on the left top side. The north and northeast side of the island as well show high slopes corresponding to the dissected valleys. The edges of the Cha di Morte also show high slope angles, whereas the south of the island shows relatively low slope angles corresponding to a smooth morphology.

609

Figure 8: Log-ratio transformed compositional biplots derived from principle component analysis. The

611 length of the black rays is proportional to the amount of variation explained by the corresponding controlling factors. Samples taken from different basins are clustered according to their calculated denudation rates with the second approach.

616 Figure 9: Denudation rates measured on different volcanic islands in the world using logarithmic scales.

617 The square symbols correspond to computed denudation rates based on eroded volume, whereas the triangles correspond to denudation rates based on ${ }^{3} \mathrm{He}$ cosmogenic concentration. 
1st approach

\begin{tabular}{|c|c|c|c|c|c|c|c|c|c|c|c|c|c|c|}
\hline \multirow[b]{2}{*}{ Sample name } & \multirow[b]{2}{*}{ Phenocryst } & \multirow[b]{2}{*}{ Fraction } & \multirow[b]{2}{*}{$\begin{array}{c}\text { Aliquot } \\
\text { mass }\end{array}$} & \multirow[b]{2}{*}{${ }^{3} \mathrm{He}$ (melt) } & \multirow[b]{2}{*}{${ }^{4} \mathrm{He}$ (melt) } & \multirow[b]{2}{*}{$\begin{array}{c}\mathrm{P}_{4} \\
\text { (radiogenic) }\end{array}$} & \multirow[b]{2}{*}{$\begin{array}{c}{ }^{4} \mathrm{He} \\
\text { (radiogenic) }\end{array}$} & \multirow[b]{2}{*}{$\begin{array}{c}\mathrm{P}_{3} \\
\text { (nucleogenic) }\end{array}$} & \multirow[b]{2}{*}{$\begin{array}{c}{ }^{3} \mathrm{He} \\
\text { (nucleogenic) }\end{array}$} & \multicolumn{2}{|l|}{ 1st approach } & \multicolumn{2}{|l|}{ 2nd approach } & \multirow[b]{2}{*}{$\begin{array}{c}\text { Integration } \\
\text { time }\end{array}$} \\
\hline & & & & & & & & & & $\begin{array}{c}{ }^{3} \mathrm{He} \\
\text { (cosmogenic) }\end{array}$ & $\begin{array}{c}\text { Denudation } \\
\text { rate }\end{array}$ & $\begin{array}{c}{ }^{3} \mathrm{He} \\
\text { (cosmogenic) }\end{array}$ & $\begin{array}{c}\text { Denudation } \\
\text { rate }\end{array}$ & \\
\hline & & $(\mu \mathrm{m})$ & (g) & $\left(10^{6} \mathrm{at} / \mathrm{g}\right)$ & $\left(10^{12} \mathrm{at} / \mathrm{g}\right)$ & $\left(10^{6} \mathrm{at} / \mathrm{g} / \mathrm{yr}\right)$ & $\left(10^{12} \mathrm{at} / \mathrm{g}\right)$ & $\left(10^{-2} \mathrm{at} / \mathrm{g} / \mathrm{yr}\right)$ & $\left(10^{4} \mathrm{at} / \mathrm{g}\right)$ & $\left(10^{6} \mathrm{at} / \mathrm{g}\right)$ & $(\mathrm{m} / \mathrm{Ma})$ & $\left(10^{6} \mathrm{at} / \mathrm{g}\right)$ & $(\mathrm{m} / \mathrm{Ma})$ & (ka) \\
\hline & & & & & & \multicolumn{3}{|c|}{ with $\mathrm{U}, \mathrm{Th}$ and $\mathrm{Sm}$ in lava $=0$} & & & & & & \\
\hline CV18-01 & $\mathrm{Px}$ & $140-500$ & 0.2331 & $21.7 \pm 1.00$ & $1.67 \pm 0.05$ & \begin{tabular}{|r|}
1.73 \\
\end{tabular} & $1.17 \pm 0.39$ & 1.57 & $1.65 \pm 0.55$ & $13.3 \pm 1.29$ & $4.67 \pm 0.46$ & $19.0 \pm 1.02$ & $3.30 \pm 0.2$ & 164 \\
\hline CV18-01 & $\mathrm{Px}$ & $140-500$ & 0.1765 & $25.3 \pm 0.06$ & $1.95 \pm 0.04$ & 1.73 & $1.17 \pm 0.39$ & 1.57 & $1.65 \pm 0.55$ & $12.1 \pm 0.85$ & $5.11 \pm 0.39$ & $22.6 \pm 0.63$ & $2.70 \pm 0.09$ & 195 \\
\hline CV18-02 & $\mathrm{Px}$ & $140-500$ & 0.2569 & $17.7 \pm 0.08$ & $5.22 \pm 0.14$ & 2.75 & $2.18 \pm 0.22$ & 0.08 & $0.08 \pm 0.01$ & & & $13.0 \pm 0.88$ & $7.40 \pm 0.66$ & 72 \\
\hline CV18-03 & $\mathrm{Px}$ & $140-500$ & 0.2404 & $17.7 \pm 0.08$ & $1.46 \pm 0.04$ & 2.25 & $1.49 \pm 0.49$ & 2.74 & $2.88 \pm 0.96$ & $17.7 \pm 1.16$ & $4.50 \pm 0.31$ & $15.4 \pm 0.85$ & $5.20 \pm 0.30$ & 103 \\
\hline CV18-03 & $P x$ & $140-500$ & 0.3403 & $16.6 \pm 0.07$ & $1.21 \pm 0.04$ & 2.25 & $1.49 \pm 0.49$ & 2.74 & $2.88 \pm 0.96$ & $16.5 \pm 1.10$ & $4.81 \pm 0.33$ & $14.3 \pm 0.77$ & $5.60 \pm 0.32$ & 96 \\
\hline CV18-04 & $P x$ & $140-500$ & 0.2558 & $29.0 \pm 1.28$ & $2.00 \pm 0.06$ & 1.38 & $0.75 \pm 0.25$ & 1.21 & $1.27 \pm 0.42$ & $7.91 \pm 1.61$ & $12.7 \pm 2.61$ & $18.2 \pm 1.37$ & $5.50 \pm 0.43$ & 96 \\
\hline CV18-04 & Px & $140-500$ & 0.1998 & $30.8 \pm 1.36$ & $2.18 \pm 0.07$ & 1.38 & $0.75 \pm 0.25$ & 1.21 & $1.27 \pm 0.42$ & $6.68 \pm 1.82$ & $15.1 \pm 4.12$ & $19.9 \pm 1.46$ & $5.00 \pm 0.38$ & 106 \\
\hline CV18-05 & $\mathrm{Px}$ & $140-500$ & 0.2374 & $9.48 \pm 0.53$ & $1.28 \pm 0.04$ & 2.15 & $2.91 \pm 1.78$ & 1.28 & $2.30 \pm 1.41$ & $9.46 \pm 1.36$ & $10.2 \pm 1.47$ & $6.34 \pm 0.56$ & $15.2 \pm 1.38$ & 35 \\
\hline CV18-05 & $\mathrm{Px}$ & $140-500$ & 0.2869 & $11.0 \pm 0.54$ & $1.41 \pm 0.04$ & 2.15 & $2.91 \pm 1.78$ & 1.28 & $2.30 \pm 1.41$ & $10.9 \pm 1.39$ & $8.80 \pm 1.13$ & $7.84 \pm 0.58$ & $12.3 \pm 0.95$ & 43 \\
\hline CV18-06 & $P x$ & $75-500$ & 0.2594 & $8.99 \pm 0.49$ & $1.26 \pm 0.04$ & 1.55 & $2.30 \pm 2.04$ & 0.80 & $1.81 \pm 1.60$ & $8.98 \pm 1.22$ & $9.06 \pm 1.24$ & $3.38 \pm 0.57$ & $24.0 \pm 4.06$ & 22 \\
\hline CV18-06 & $\mathrm{Px}$ & $75-500$ & 0.2546 & $13.6 \pm 0.34$ & $2.39 \pm 0.05$ & 1.55 & $2.30 \pm 2.04$ & 0.80 & $1.81 \pm 1.60$ & $12.0 \pm 0.96$ & $6.77 \pm 0.56$ & $7.94 \pm 0.44$ & $10.2 \pm 0.61$ & 52 \\
\hline CV18-07 & $P x$ & $75-500$ & 0.2846 & $15.7 \pm 0.72$ & $1.26 \pm 0.04$ & 1.15 & $2.83 \pm 1.64$ & 1.17 & $5.55 \pm 3.22$ & $15.5 \pm 1.98$ & $6.41 \pm 0.83$ & $9.49 \pm 0.79$ & $10.4 \pm 0.90$ & 51 \\
\hline CV18-07 & $P x$ & $75-500$ & 0.2764 & $20.2 \pm 0.45$ & $1.54 \pm 0.03$ & 1.15 & $2.83 \pm 1.64$ & 1.17 & $5.55 \pm 3.22$ & $20.2 \pm 1.76$ & $4.91 \pm 0.44$ & $14.2 \pm 0.56$ & $7.00 \pm 0.31$ & 77 \\
\hline CV18-08 & $\mathrm{Px}$ & $140-500$ & 0.2884 & $8.90 \pm 0.48$ & $2.01 \pm 0.06$ & 2.41 & $6.10 \pm 5.34$ & 1.79 & $7.17 \pm 6.28$ & $8.83 \pm 3.34$ & $10.4 \pm 3.94$ & $3.87 \pm 0.58$ & $23.7 \pm 3.58$ & 23 \\
\hline CV18-08 & $\mathrm{Px}$ & $140-500$ & 0.2852 & $9.18 \pm 0.26$ & $1.93 \pm 0.04$ & 2.41 & $6.10 \pm 5.34$ & 1.79 & $7.17 \pm 6.28$ & $9.11 \pm 3.27$ & $10.1 \pm 3.62$ & $4.16 \pm 0.41$ & $22.1 \pm 2.21$ & 24 \\
\hline CV18-09 & $\mathrm{Px}$ & $140-500$ & 0.2846 & $3.78 \pm 0.29$ & $1.40 \pm 0.04$ & 1.90 & $1.17 \pm 0.39$ & 1.29 & $1.36 \pm 0.45$ & & & $2.76 \pm 0.36$ & $33.3 \pm 4.41$ & 16 \\
\hline CV18-10 & $P x$ & $140-500$ & 0.3100 & $6.25 \pm 0.37$ & $1.45 \pm 0.04$ & 2.43 & $3.32 \pm 3.07$ & 1.88 & $4.06 \pm 3.76$ & $6.21 \pm 1.76$ & $14.8 \pm 4.23$ & $4.99 \pm 0.44$ & $18.4 \pm 1.69$ & 29 \\
\hline CV18-11 & $P x$ & $140-500$ & 0.2705 & $2.91 \pm 0.27$ & $1.46 \pm 0.04$ & 2.44 & $4.55 \pm 3.37$ & 1.21 & $3.28 \pm 2.43$ & $2.88 \pm 2.26$ & $31.9 \pm 25.11$ & $2.03 \pm 0.29$ & $45.2 \pm 6.65$ & 12 \\
\hline CV18-11 & $P x$ & $140-500$ & 0.3562 & $5.48 \pm 0.16$ & $2.55 \pm 0.05$ & 2.44 & $4.55 \pm 3.37$ & 1.21 & $3.28 \pm 2.43$ & $5.45 \pm 1.87$ & $16.9 \pm 5.81$ & $4.61 \pm 0.21$ & $20.0 \pm 0.98$ & 27 \\
\hline CV18-12 & Px/oliv & $140-500$ & 0.2466 & $3.01 \pm 0.31$ & $1.51 \pm 0.04$ & 2.48 & $4.18 \pm 3.64$ & 1.20 & $2.77 \pm 2.41$ & $2.98 \pm 1.92$ & $32.1 \pm 20.1$ & $2.96 \pm 0.33$ & $32.2 \pm 3.68$ & 17 \\
\hline CV 18-12 & Px/oliv & $140-500$ & 0.2837 & $2.61 \pm 0.19$ & $2.08 \pm 0.04$ & 2.48 & $4.18 \pm 3.64$ & 1.20 & $2.77 \pm 2.41$ & $2.58 \pm 1.66$ & $37.1 \pm 23.8$ & $2.56 \pm 0.17$ & $37.4 \pm 2.57$ & 14 \\
\hline CV18-13 & $\mathrm{Px}$ & $140-500$ & 0.2459 & $4.09 \pm 0.34$ & $1.33 \pm 0.04$ & 1.56 & $3.37 \pm 1.95$ & 1.61 & $7.63 \pm 4.42$ & $4.01 \pm 2.64$ & $19.1 \pm 12.6$ & $3.59 \pm 0.37$ & $21.4 \pm 2.24$ & 25 \\
\hline CV18-14 & $\mathrm{Px}$ & $140-500$ & 0.2991 & $4.23 \pm 0.29$ & $0.94 \pm 0.03$ & 4.36 & $8.37 \pm 7.28$ & 1.42 & $3.26 \pm 2.84$ & $4.20 \pm 3.82$ & $16.6 \pm 15.1$ & $3.29 \pm 0.37$ & $21.3 \pm 2.45$ & 25 \\
\hline CV18-17 & $P x$ & $140-500$ & 0.3099 & $4.44 \pm 0.29$ & $5.60 \pm 0.15$ & 12.5 & $33.6 \pm 29.0$ & 2.86 & $8.29 \pm 7.14$ & $4.36 \pm 13.0$ & $21.1 \pm 62.8$ & $3.11 \pm 0.34$ & $29.5 \pm 3.25$ & 18 \\
\hline CV18-18 & $P x$ & $140-500$ & 0.1818 & $10.8 \pm 0.63$ & $2.70 \pm 0.08$ & 4.06 & $4.58 \pm 3.16$ & 1.58 & $2.29 \pm 1.58$ & $10.8 \pm 1.96$ & $6.11 \pm 1.11$ & $10.1 \pm 0.64$ & $6.51 \pm 0.44$ & 82 \\
\hline CV18-19 & Px/oliv & $140-500$ & 0.3134 & $2.88 \pm 0.25$ & $1.57 \pm 0.04$ & 0.91 & $1.08 \pm 0.47$ & 0.42 & $0.87 \pm 0.38$ & & & $2.63 \pm 0.28$ & $39.9 \pm 4.35$ & 13 \\
\hline CV18-20 & Px/oliv & $140-500$ & 0.3135 & $2.53 \pm 0.24$ & $3.49 \pm 0.09$ & 1.01 & $1.21 \pm 0.53$ & 0.41 & $0.85 \pm 0.37$ & & & $1.94 \pm 0.29$ & $57.5 \pm 3.84$ & 9 \\
\hline CV18-25 & $\mathrm{Px}$ & $140-500$ & 0.2216 & $2.20 \pm 0.30$ & $1.12 \pm 0.03$ & 0.93 & $1.57 \pm 1.04$ & 1.09 & $4.92 \pm 3.28$ & $2.15 \pm 1.43$ & $47.2 \pm 31.4$ & $2.08 \pm 0.35$ & $47.8 \pm 8.16$ & 11 \\
\hline CV18-26 & Px/oliv & $140-500$ & 0.2916 & $4.20 \pm 0.30$ & $1.42 \pm 0.04$ & 1.21 & $1.47 \pm 1.47$ & 0.64 & $1.29 \pm 1.29$ & $4.18 \pm 0.85$ & $26.1 \pm 5.35$ & $2.98 \pm 0.35$ & $36.6 \pm 4.37$ & 15 \\
\hline CV18-27 & Px/oliv & $140-500$ & 0.2925 & $13.1 \pm 0.58$ & $0.13 \pm 0.01$ & 13.1 & $1.25 \pm 0.03$ & 3.45 & $0.36 \pm 0.01$ & $13.1 \pm 0.80$ & $9.34 \pm 0.60$ & $12.6 \pm 0.62$ & $9.65 \pm 0.51$ & 55 \\
\hline CV18-28 & Px/oliv & $140-500$ & 0.3783 & $14.6 \pm 0.66$ & $4.80 \pm 0.13$ & 4.36 & $0.93 \pm 0.31$ & 2.25 & $0.67 \pm 0.22$ & & & $12.9 \pm 0.68$ & $5.33 \pm 0.27$ & 100 \\
\hline CV18-29 & $\mathrm{Px}$ & $140-500$ & 0.2037 & $13.4 \pm 0.68$ & $0.60 \pm 0.02$ & 1.26 & $0.67 \pm 0.27$ & 0.74 & $0.73 \pm 0.29$ & $13.3 \pm 0.84$ & $6.31 \pm 0.42$ & $13.0 \pm 0.71$ & $6.46 \pm 0.37$ & 83 \\
\hline
\end{tabular}




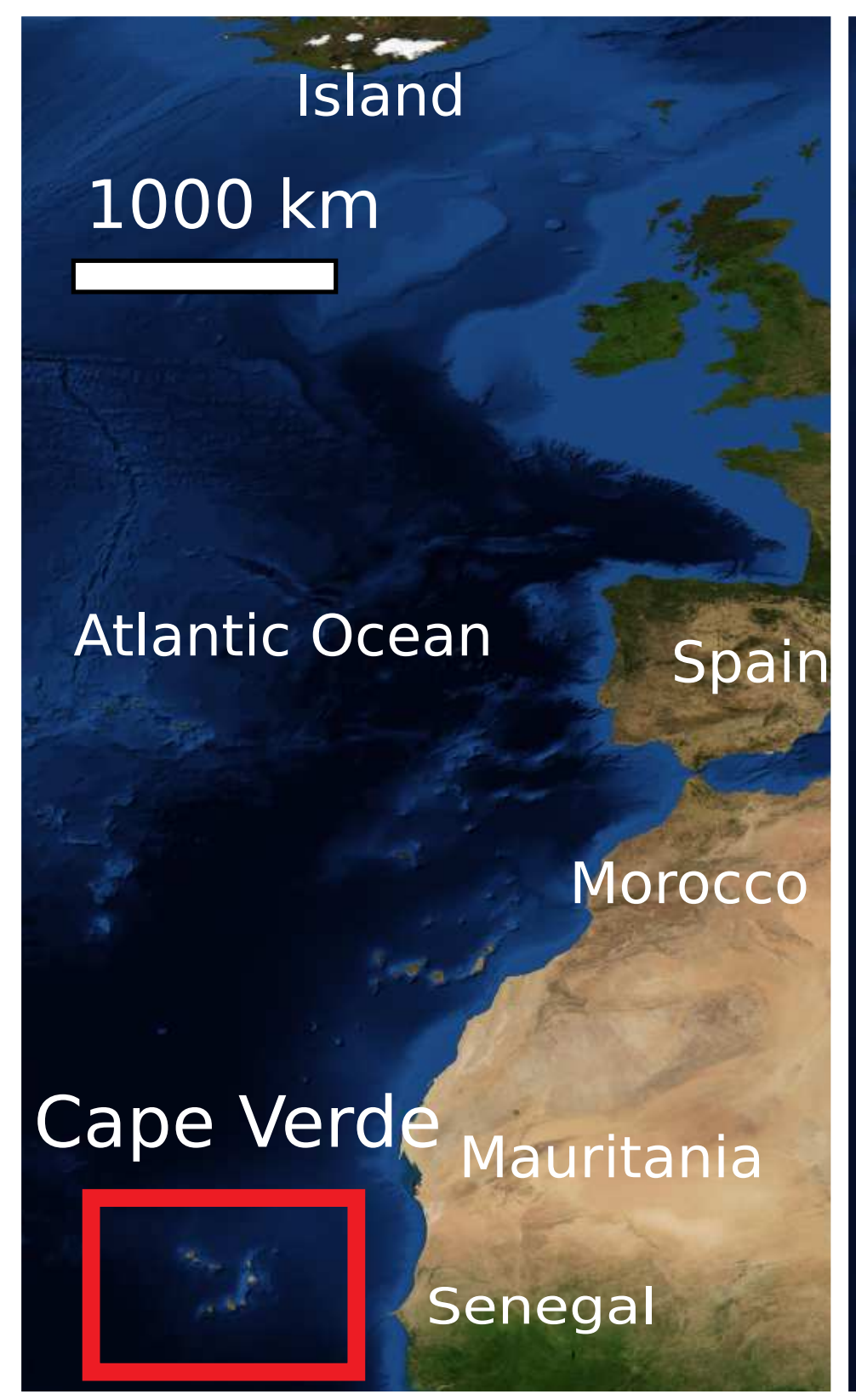

\section{$--5^{25^{\circ}}$ Santo Antao $-2-05$ San Vicente \\ Santa Luzia}

Sao Nicolau

\section{$23^{\circ} \mathrm{W}$}

$17^{\circ} \mathrm{N}-$

Sal
Atlantic Ocean

Spain

Morocco

Cape Verde Mauritania

\section{Senegal}

$15^{\circ} \mathrm{N}=$

Brava
Santiago

Maio

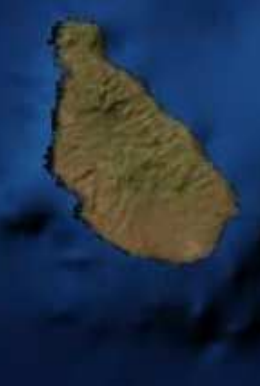

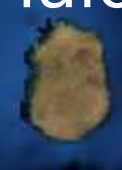

$100 \mathrm{~km}$ 


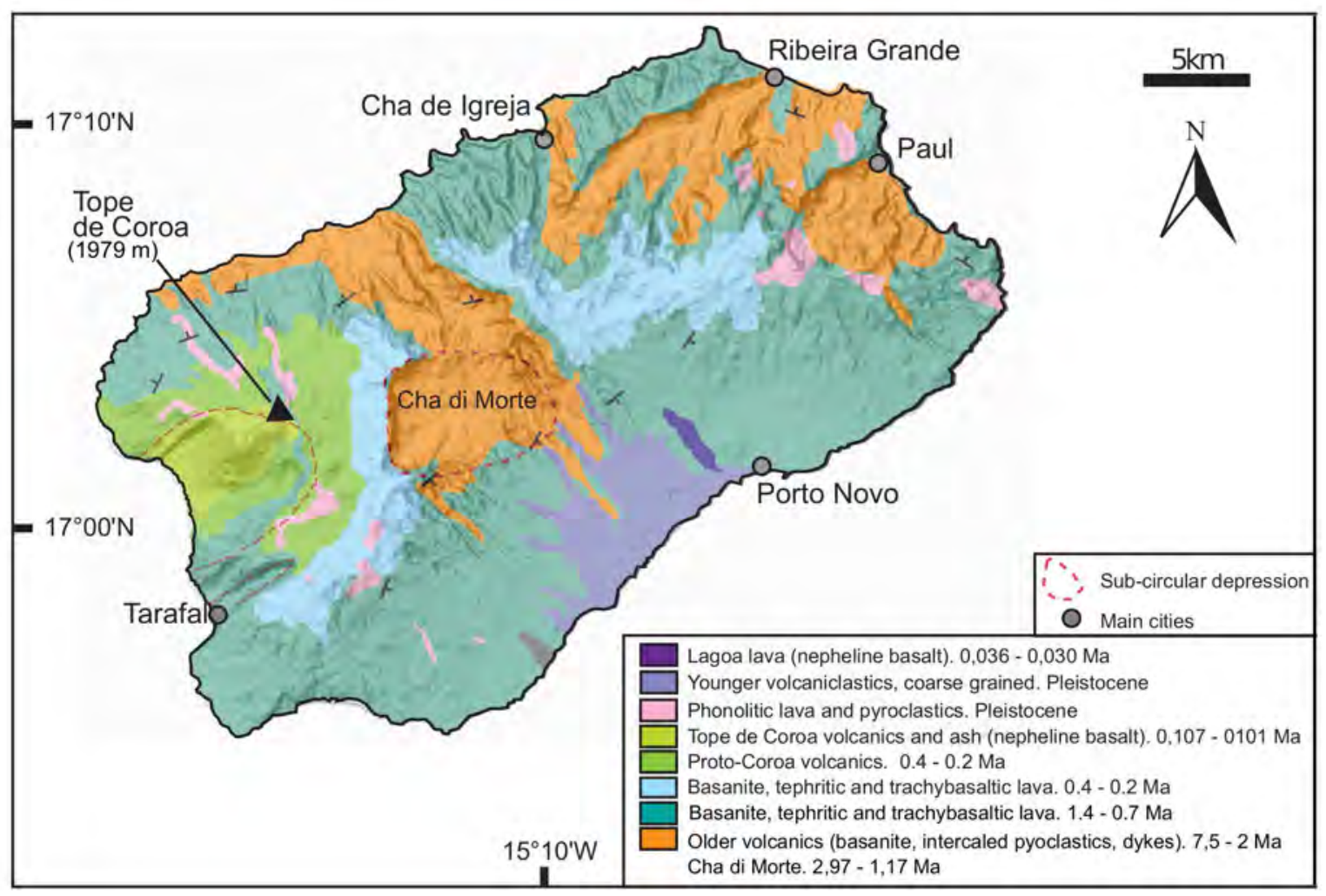




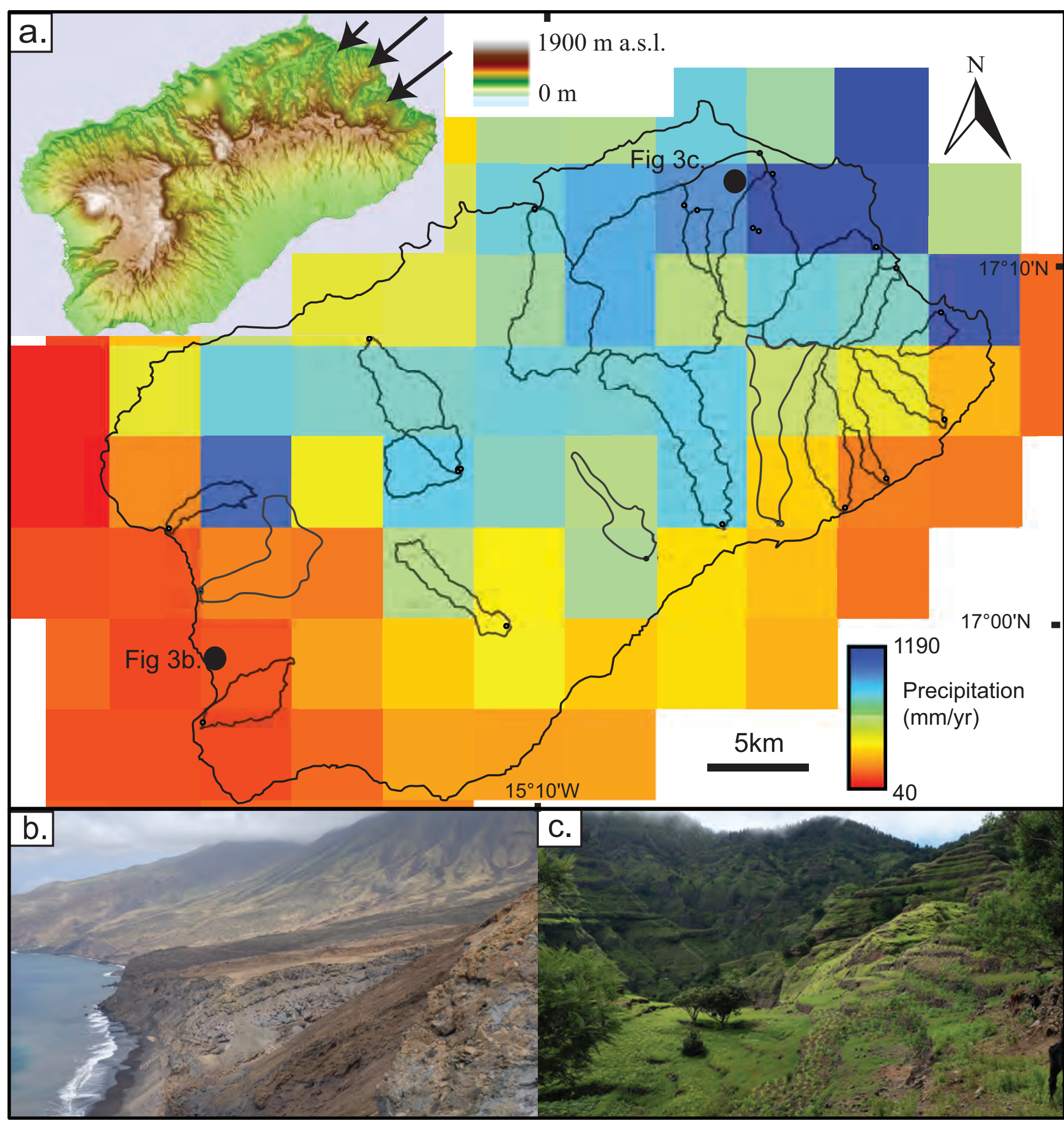



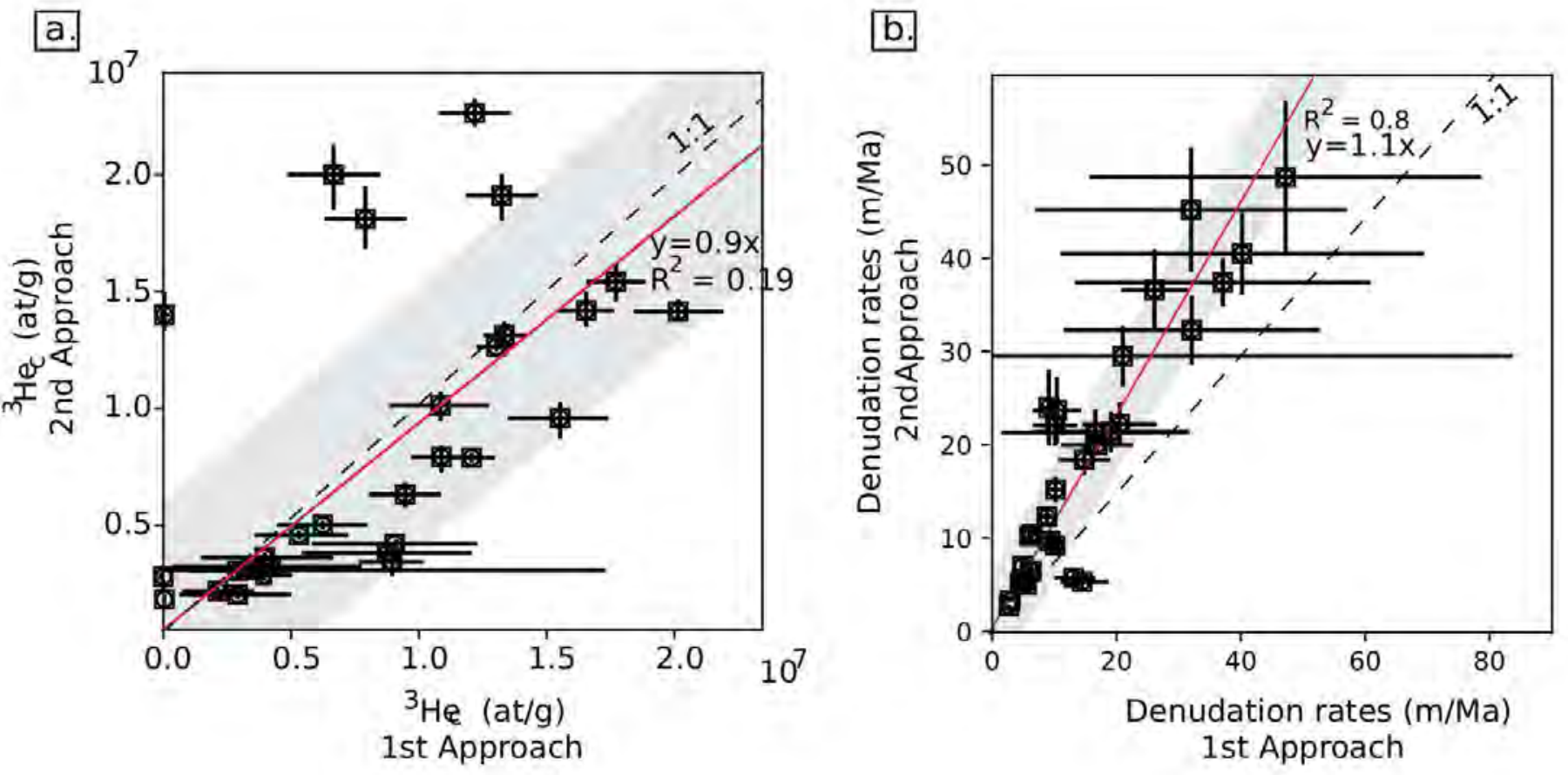

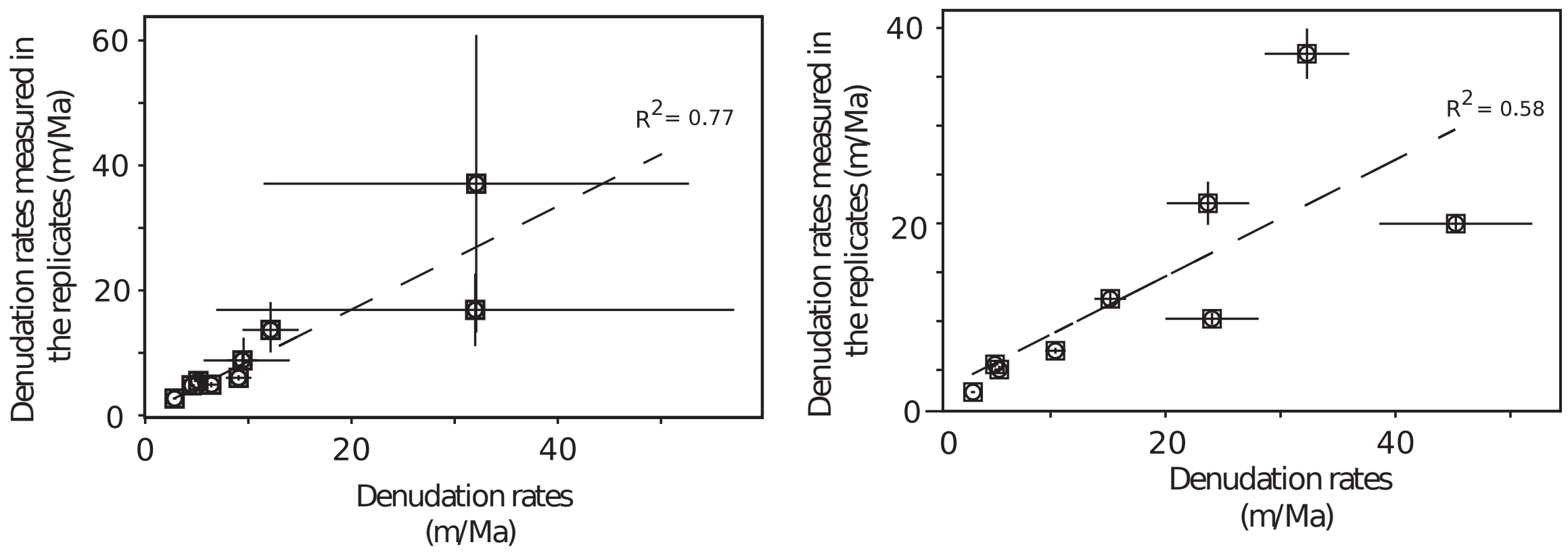

c.The 2 approaches combined

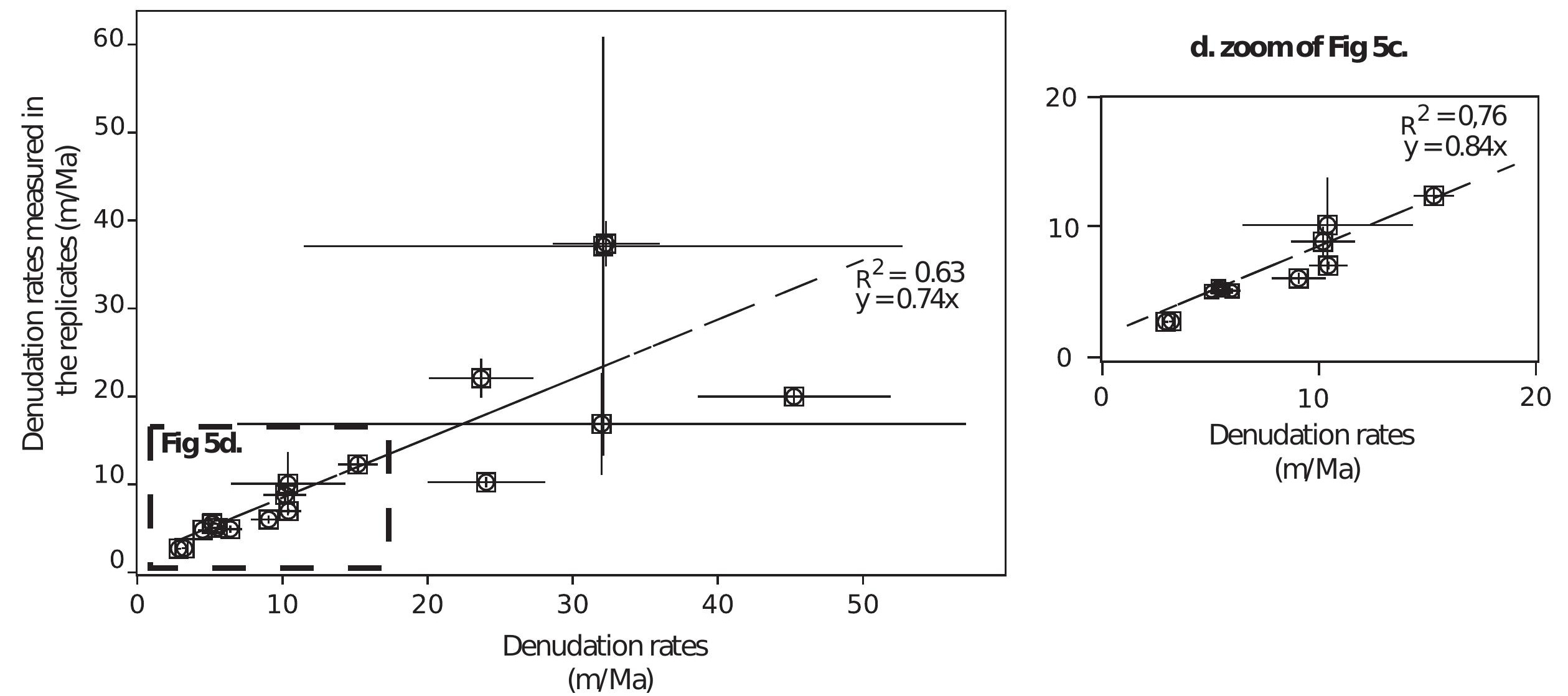




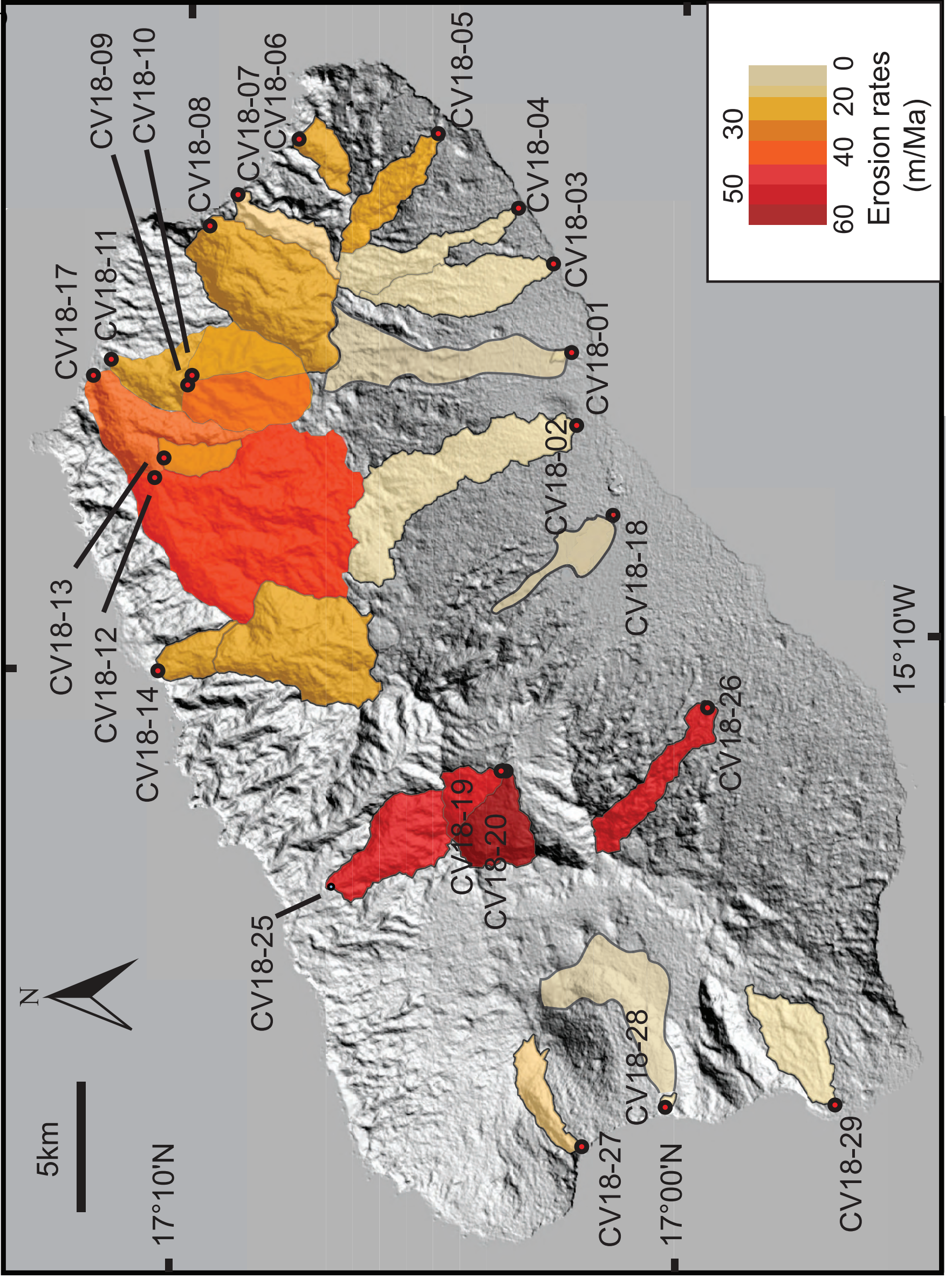




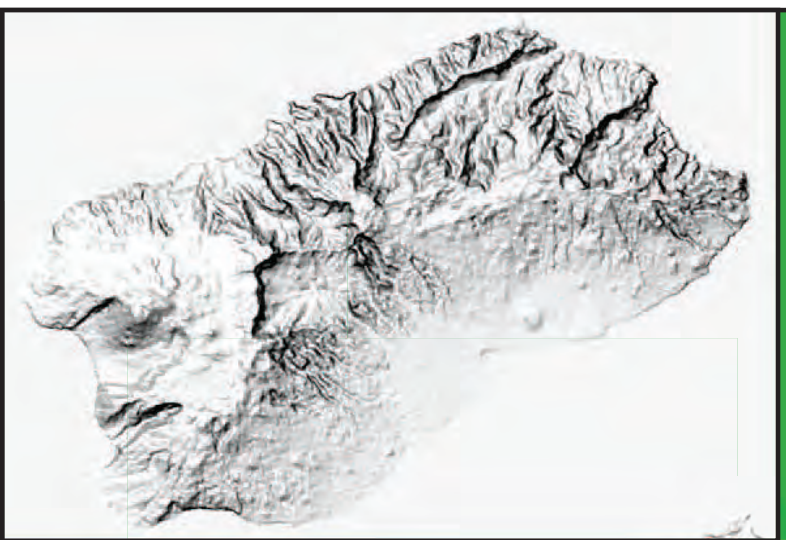

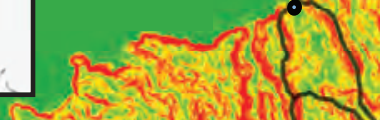

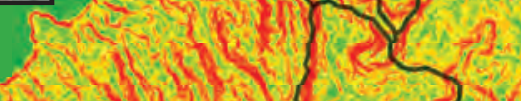
axing des?

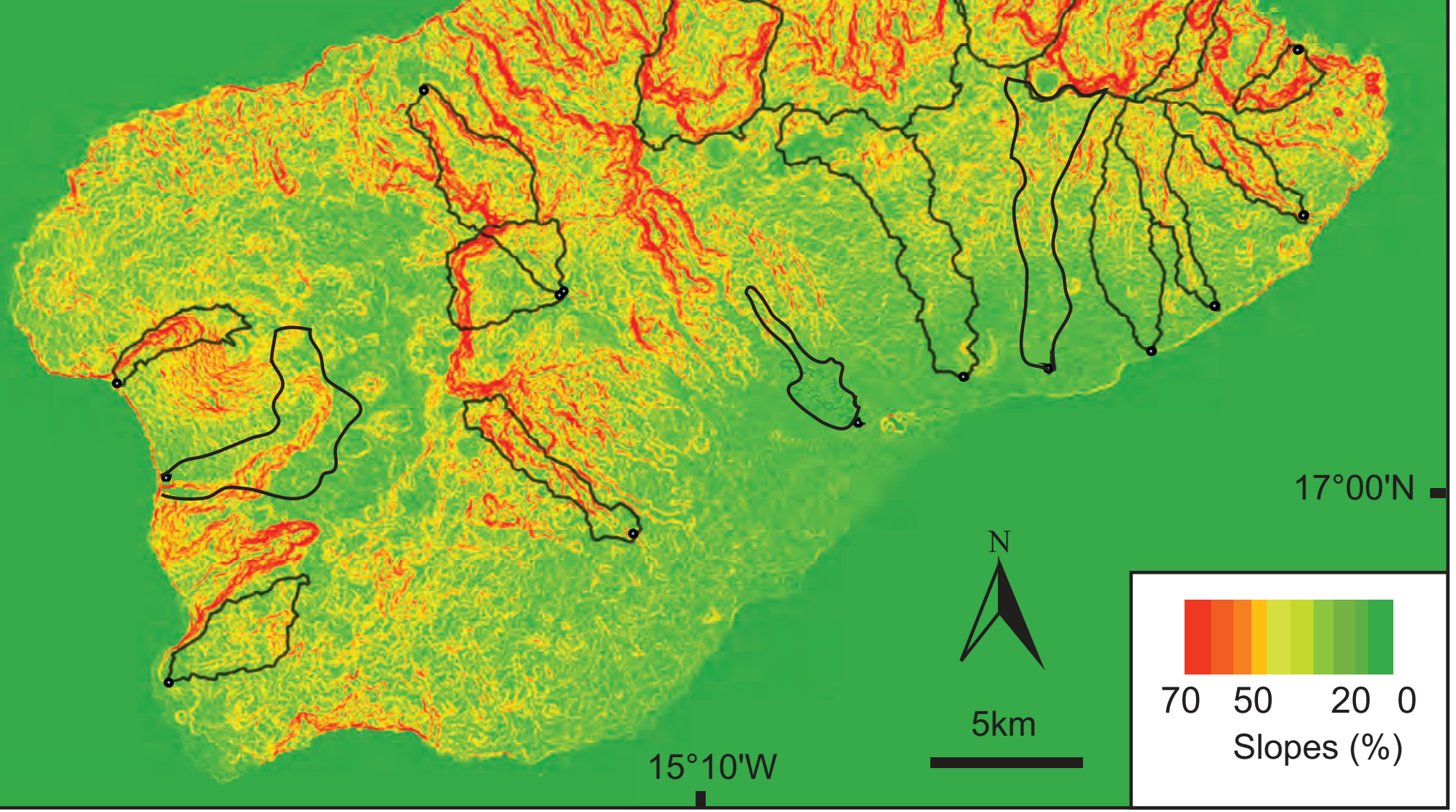




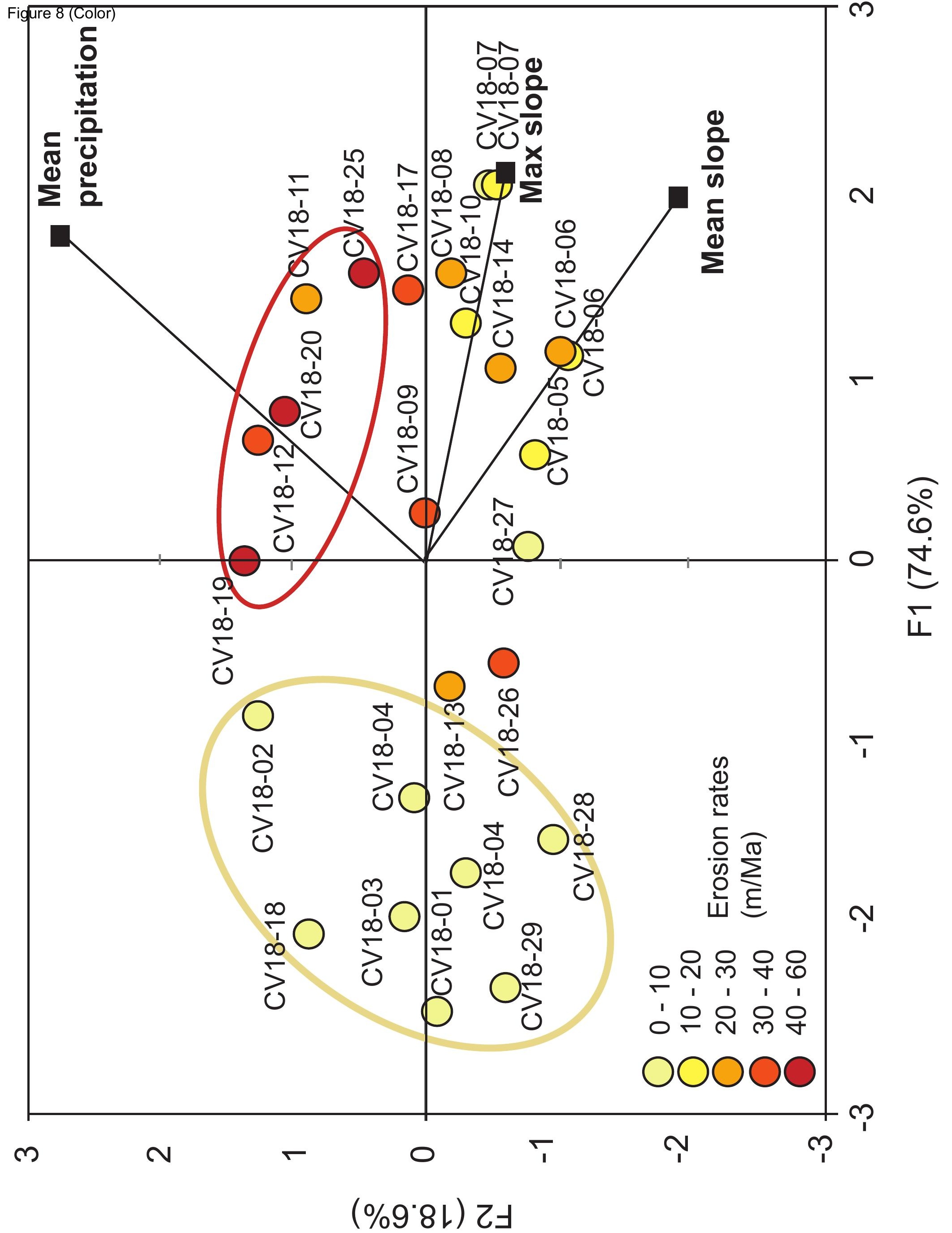




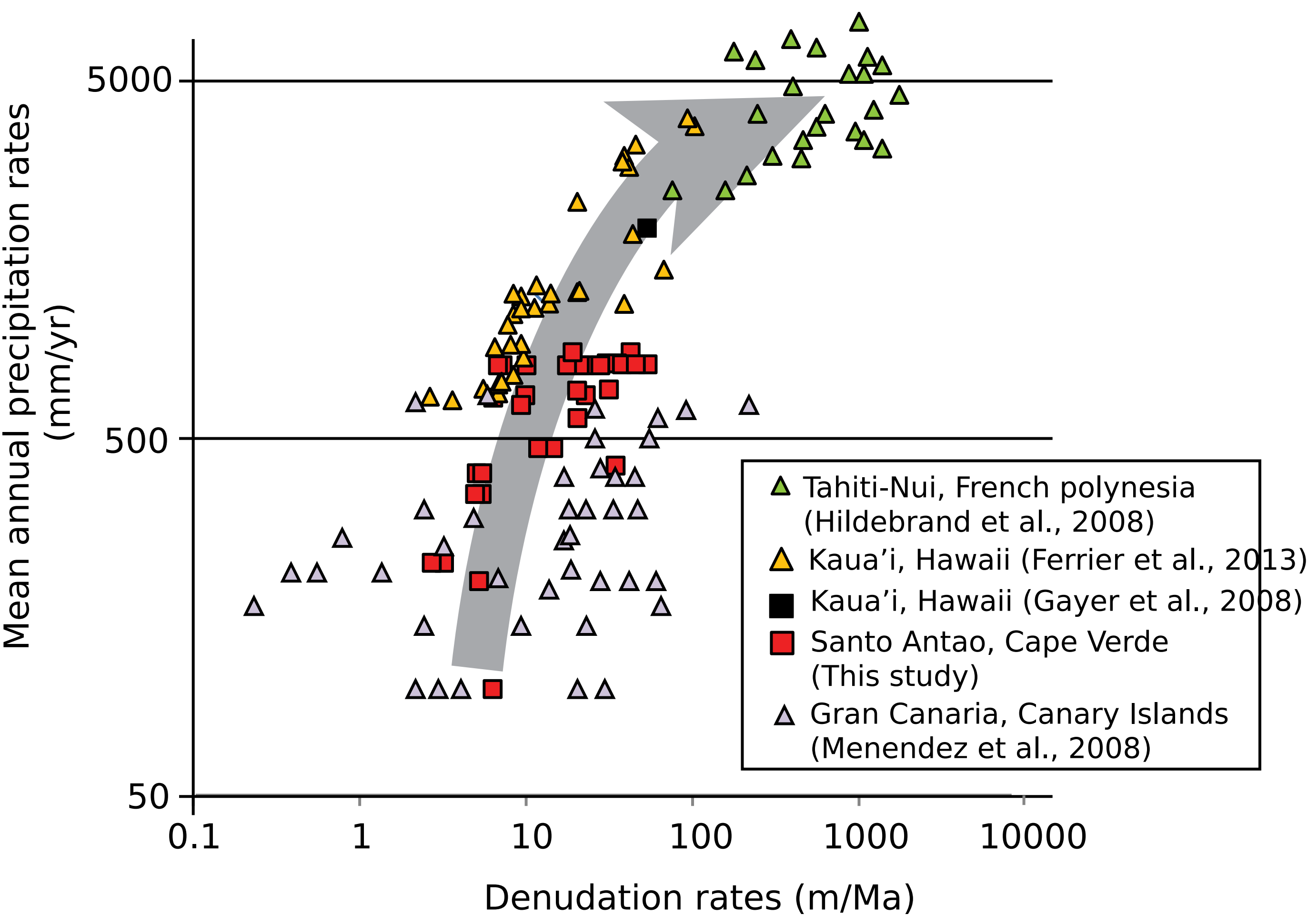


Click here to access/download Supplementary material for online publication only
TableA1.xlsx 
Click here to access/download Supplementary material for online publication only TableA2.xIsx 
Click here to access/download Supplementary material for online publication only TableA3.xIsx 